\title{
Housing Wealth, Credit Conditions and Consumption
}

\author{
JANINE ARON \\ Centre for the Study of African Economies, Department of Economics, \\ University of Oxford, England \\ JOHN MUELLBAUER \\ Nuffield College, University of Oxford, England \\ and \\ ANTHONY MURPHY \\ Hertford College, University of Oxford, England
}

February, 2007

\begin{abstract}
There is widespread disagreement about the role of housing wealth in explaining consumption. Much of the empirical literature is marred by poor controls for the common drivers of house prices and consumption, including income, income growth expectations, interest rates, credit supply conditions, other assets and indicators of income uncertainty (such as changes in the unemployment rate). For instance, while the easing of credit supply conditions is usually followed by a house price boom, failure to control for the direct effect of credit liberalization on consumption can over-estimate the effect of housing wealth or collateral on consumption. This paper suggests an empirical model grounded in theory with more complete controls than hitherto used. It is applied to modeling consumption in the UK and South Africa. Both countries experienced substantial credit market liberalization and rising consumption to income ratios. However, South Africa's circumstances in the 1980s prevented an asset price boom, thus allowing the illumination of the direct role of credit liberalization. The paper incorporates methodological improvements in the measurement of credit conditions, and also clarifies the multi-faceted effects of credit liberalization on consumption.
\end{abstract}

\footnotetext{
* This is a revised and extended version of Aron and Muellbauer (2000b), incorporating UK evidence, and updating the South African wealth data. We are grateful for comments on earlier drafts from Olympia Bover, Angus Deaton, Jim Poterba and seminar participants at the IMF, Oxford and HM Treasury. We are very grateful for data discussions to Michael Kock, Danie Meyer, Coen Pretorius, Johan Prinsloo and Johan van den Heever of the South African Reserve Bank. This research was funded by the Department for International Development (grant numbers R7291, R7911 and R8311), an Economic and Social Research Council Research Fellowship (H52427003594), and ESRC grant (RES-000-23-0244). The U.K. Department for International Development (DFID) supports policies, programmes and projects to promote international development. DFID provided funds for this study as part of that objective but the views and opinions expressed are those of the authors alone. Our South African research can be found at: http://www.csae.ox.ac.uk/, link to "The South African Macroeconomic Research Programme".
} 


\section{Introduction}

There is widespread concern among central banks about the influence of house prices on consumption, and much current debate on how monetary policy should react to asset price fluctuations in the context of liberalised credit markets (see Rajan (2005) and associated papers from the Jackson Hole symposium). Housing markets and their consumption interactions have, in recent years, become a very active research area. ${ }^{1}$ Nevertheless there is disagreement about the role of housing wealth in explaining consumption.

Unfortunately, much of the empirical literature, both macro and micro, is marred by poor controls for the common drivers both of house prices and consumption, including income, income growth expectations, interest rates, credit supply conditions, other assets and indicators of income uncertainty (such as the changes in the unemployment rate). For example, the easing of credit supply conditions is usually followed by a house price boom. Failure to control for the direct effect of such easing on consumption can result in overestimates of the effect of housing wealth or collateral on consumption. Our review of the literature in Section 2 illustrates these points; and in Sections 4 and 5, we provide specific evidence through comparisons of well-specified empirical models with those omitting relevant controls.

In this paper we apply an empirical model incorporating more complete controls than are generally employed in the literature. These controls include a measure of consumer credit conditions and its interactions with a variety of economic variables such as proxies for income uncertainty, income growth expectations and interest rates. Furthermore, we include a coherent treatment of income growth expectations, missing from most published research. The application is to the UK, and to an emerging market country, South Africa. Both countries experienced substantial credit market liberalization and rises in consumption to income ratios. However, in South Africa, due to particular circumstances in the $1980 \mathrm{~s}$, this occurred without an asset price boom, thus illuminating the direct role of credit liberalization.

The paper incorporates methodological improvements in the measurement of credit conditions, and also clarifies the multi-faceted effects of credit liberalization on consumption. For the UK, we capture the direct and interaction effects of financial liberalization on

\footnotetext{
${ }^{1}$ There are now attempts to introduce housing into DSGE models, Iacoviello (2005), and to give some microfoundations to the financial accelerator via households, Aoki et al (2004). Lustig and van Niewerburgh (2005) have analysed the introduction of housing collateral into consumption capital asset pricing models. Recent empirical studies of the housing-consumption link on macroeconomic data include Case et al (2005), Catte et al
} 
consumption by employing a consumer credit conditions index, derived by FernandezCorugedo and Muellbauer (2006). They model data on ten credit indicators, from which a common credit indicator and a risk indicator are extracted, after controlling for standard economic and demographic variables. For South Africa, we estimate joint debt and consumption equations with an unobservable credit supply indicator entering both consumption and debt equations. This indicator is proxied by a linear spline function and the parameters are estimated, subject to cross-equation restrictions, from a joint estimation of the household consumption and debt equations incorporating institutional information on credit market liberalization in South Africa.

Furthermore, we distinguish theoretically and empirically among three types of effect of financial liberalization on consumption, which previous literature does not bring out clearly. Financial liberalization reduces the credit constraints on households engaging in smoothing consumption when they expect significant income growth; it reduces deposits required of first-time buyers of housing; and it increases the availability of collateral-backed loans for households which already possess collateral. The three facets imply both a shift in the average propensity to consume, and important interaction effects, for example with housing wealth, income growth expectations, interest rates and indicators of uncertainty.

Our empirical evidence supports these three facets of financial liberalization on consumption and suggests for the UK, that after credit market liberalization, the marginal propensity to spend out of housing wealth is approximately the same as that out of illiquid financial wealth, but less than that out of net liquid assets. It suggests that in countries with less liberal credit markets and weaker access by mortgage lenders to housing collateral than in the UK, the marginal propensity to spend out of housing wealth is likely to be smaller than from stock market wealth. For South Africa, where credit markets are now quite liberal, the marginal propensity to spend out of housing wealth appears to exceed that for illiquid financial wealth, but is less than that out of net liquid assets.

The outline of the paper is as follows. Section 2 reviews the empirical literature on housing wealth effects. Section 3 provides a theoretical background for the econometric specification applied to time series data for the UK in Section 4, and South Africa in Section 5. Section 6 briefly concludes. 


\section{Literature Review}

We compare and contrast a range of micro- and macro-economics studies on consumption and wealth using Table 1, which distinguishes amongst studies on several criteria including the economic controls employed in the consumption models. The first criterion is whether studies satisfy approximate long-run homogeneity of consumption in income and wealth, and whether they permit heterogeneity across countries, where relevant. The economic controls include income, income growth expectations, and credit conditions as intercept shift and interaction effects. Wealth effects are divided into log and level specifications and the level of disaggregation of wealth used. The theoretical section (Section 3) below argues that levels of wealth to income are preferable to logs, and that some disaggregation is desirable. Other controls are interest rate effects and uncertainty proxies.

In a widely-cited study, Case, Quigley and Shiller (2005) claim that for a panel of US states and a panel of 14 countries, the housing wealth effect is larger than the stock market wealth effect. However, the econometrics is questionable. Their equilibrium correction model (ECM) used both for the panels of US states and OECD countries, takes the form

$$
\begin{aligned}
\Delta \log c_{t}= & \alpha \Delta \log c_{t-1}+\beta_{1} \Delta \log y_{t}+\beta_{2} \Delta \log \text { stock }_{\mathrm{t}}+\beta_{3} \Delta \log \text { house }_{\mathrm{t}} \\
& +\gamma\left[\log c_{t-1}-\log y_{t-1}\right]+\beta_{4} \Delta \log \text { stock }_{\mathrm{t}-1}+\text { fixed effects }+\varepsilon_{\mathrm{t}}
\end{aligned}
$$

where $y$ is income, stock is stock market wealth, and house is owner-occupied housing wealth, all in real per capita terms. A 1986 dummy interacted with $\Delta \log$ (house) tests for shifts in behaviour, for example, connected with shifts in credit market conditions.

However, among the omitted controls are levels of housing asset and stock market wealth, interest rates, the unemployment rate, and income growth expectations. It can also be argued that for the US states, stock market wealth is imputed to the state levels with rather crude methods, although the housing wealth data are better measured. Changes in housing market wealth at the state level are likely to be strongly correlated with missing unemployment data, mis-measured income growth and omitted income growth expectations. The wealth data are end-of-period data which will increase their endogeneity (though the authors claim changes in timing have little effect on the estimates). 
For the OECD part of their study, pooling the 14 countries denies the heterogeneity between countries implied by institutional differences, see Maclennan et al (1998,2000). Shifts in credit conditions are also omitted from the OECD country data, yet Finland, Norway, Sweden, the UK and the Netherlands, for example, all underwent revolutions in credit availability. The rise in house prices is highly correlated with the shift in credit conditions. It is not surprising that the estimated housing wealth effect is larger for the OECD countries, where credit conditions went through larger changes than for US states after 1982.

In contrast to Case et al., Catte et al. (2004) note institutional differences amongst countries and find major heterogeneity for the parameters in different OECD economies. They estimate ECM models which do have long-run wealth effects, as well as interest rate and unemployment effects. However, they do not control for income expectations explicitly, or for the effects of financial liberalization, and this is liable to bias up the estimated housing wealth or collateral effects on consumption. This is equally true of Kennedy and Andersen (1994) who study consumption in the form of saving ratios. Nevertheless, the latter study confirms the heterogeneity of wealth effects across countries, finding an apparently negative housing wealth effect for Italy, which could feasibly be reflecting its poorly functioning mortgage market.

Boone et al (2001) are sensitive to the potential importance of credit market liberalization and find some evidence for shifts in long-run relationships, particularly for the UK, US and Canada, using dummies for credit market liberalization. They also control for interest rate and unemployment dynamics. They too find a negative housing wealth coefficient for Italy. However, they do not attempt to control for income growth expectations or the effect of credit market liberalization on the long-term consumption to income ratio. The implication is that housing wealth effects may well be upward biased for the UK, US and Canada. Ludwig and Sloek (2002) examine data for 16 OECD countries, using stock market and house price indices, the latter of sometimes questionable quality. They group countries into two, by whether they have bank-based or market-based financial systems, and impose common slope parameters within each group. They find strong long-run stock market effects and less well estimated house price effects, with some evidence of larger coefficients for post 1985 data than for pre 1985 data. Other relevant controls are all missing.

Dvornak and Kohler (2003) study a panel of Australian states for 1984-2001, disaggregating wealth into net housing wealth, stock market wealth and other wealth. They find the marginal propensity to spend of stock market wealth to exceed that from net housing wealth, but the omission of controls for income growth expectations, shifts in credit 
conditions, unemployment and interest rates may well have biased upwards the estimated wealth effects.

Two studies by Barrell and Davis (2004) and Byrne and Davis (2003) estimate equations for the G-5 and G-7 countries, respectively, employing no controls for shifts in credit conditions, interest rates, unemployment rates or expected income growth. The former paper aggregates wealth into net worth in $\log$ form. In the latter paper, they also do not distinguish housing wealth, but test for differences between liquid and illiquid assets effects. For most countries, Byrne and Davis (2003) find liquid asset effects smaller than those from illiquid assets, and typically negative for the US, and especially the UK. Since liquid assets are defined as gross liquid assets minus debt, this is a classic symptom of omitted variable bias. Credit market liberalization is associated with rises in debt relative to income and relative to gross liquid assets. It has a positive effect on consumption but is negatively correlated with net liquid assets, and so its omission biases the latter's effect in a negative direction.

This illustrates the point that for aggregate time series data, the failure to control for shifts in credit conditions is often likely to be critical. Although the implications of financial liberalization have aroused interest, controversy, and a literature (such as Bayoumi 1993a, 1993b; Schmidt-Hebbel and Serven 1997, 1999; Bandiera et al 2000; Honohan 1999), there has not been an entirely satisfactory applied analysis of these implications in the consumption literature. One major difficulty has been to find an indicator of credit market deregulation with which to model the direct and interaction effects of financial liberalization.

Muellbauer and Murphy $(1993,1995)$ study annual respectively UK national and regional panel data for 11 regions with a more complete set of controls than other studies. They capture income growth expectations through the fitted values from parsimonious income forecasting equations, and check for interaction effects of these with uncertainty indicators. The shifts in credit conditions are proxied using an indicator derived from data on loan-to-value ratios for mortgages to first-time buyers, see Muellbauer and Murphy (1993) - a forerunner of the indicator discussed below in Section 4.2. Interest rate and unemployment effects are included. Assets are aggregated into liquid and illiquid categories (measured at the end of the previous year), where the latter includes housing wealth, and shifts in wealth effects with credit conditions are tested for. As a check on the aggregation of physical and 
financial illiquid wealth, a separate allowance is made for a real house price effect, but this always proves insignificant. $^{2}$

We turn to two studies of consumption employing similar micro-economic data for the UK, but which have reached diametrically opposed conclusions through the different controls they employ. Attanasio et al. (2005) explain consumption spending in terms of age and cohort dummies, household demography, housing tenure, and regional house price growth rates and the level of house prices ${ }^{3}$. They find the largest house price growth rate effects for the young, followed by the middle aged and then the old (and similar effects for renters as for home-owners). This is counterintuitive since housing wealth increases with age. The log level of regional house prices has a similar effect for all three age groups. However, the residuals from regressing regional house prices on regional incomes, a simple attempt to remove the influence of regional income, have their biggest effects on the young. Attanasio et al. try to explain these anomalous findings by arguing that since housing wealth increases with age, house prices are merely a proxy for omitted income expectations, and probably have no independent role to play in explaining consumption.

By contrast, Campbell and Cocco (2005) explain changes in consumption per head for different cohorts classified by region, controlling for income growth, regional unemployment, for interest rates as well as housing tenure, mortgage debt and regional house prices $^{4}$. They find the largest house price effects for the older home-owners, and the lowest effects for renters ${ }^{5}$.

Their findings suggest that those of Attanasio et al. are due to poor economic controls. Since consumption is likely to strongly influenced by current income, and also by financial asset ownership (also increasing with age and differing by region), debt and variations in unemployment rates and interest rates, the failure to control for these other variables implies that no conclusions about the effects of housing assets on consumption can be drawn from the study of Attanasio et al. The consumption of the young is likely to be the most sensitive to current income, and regional house prices are correlated with current income. Further, the

\footnotetext{
2 One shortcoming of these studies is the omission of the direct effect on consumption of credit conditions (discussed below). The authors were also sceptical over the accuracy of the regional accounts income data. Subsequently, Cameron and Muellbauer (2000) established that these data seriously understated the rise in relative incomes in the South East in the 1980s, probably resulting in an upward bias in the housing wealth effects being estimated. For this reason, the authors did not attempt to publish the regional study.

${ }^{3}$ They use micro data from the Family Expenditure Survey for 1978-2001.

${ }^{4}$ They use micro data from the FES from 1988-2000.

5 The fact that the latter (in the form of national house prices) is still significant suggests that house prices contain a general 'confidence' or expectations effect, in addition to whatever wealth or collateral role they play.
} 
collateral role of housing wealth suggests that young house owners, who are more likely to be credit-constrained, could well be as sensitive as older owners to rises in house prices. Moreover the relaxation of UK credit constraints in the 1980s would have had a larger effect on the consumption of the young, than of the old, so inducing a correlation of their consumption with house prices, but without a shift in wealth or in income growth expectations. Campbell and Cocco largely avoid this difficulty by beginning their sample in 1988, after the major liberalization of credit.

A related study on panel data for US households for 1968-99 from the PSID, Lehnert (2004), finds the largest consumption growth rate in response to the growth rate of house prices for the 52-62 age group, contradicting Attanasio et al's findings. Lehnert also finds the youngest households to be more responsive than middle-aged households, to which he gives the interpretation of a relaxation of credit constraints. While his study includes time dummies, and is therefore largely protected from the criticism of omitted controls, he does not check whether the estimated responses evolve over time.

Bover (2005) and Bostic et al (2005) studied housing wealth effects, respectively on Spanish and US cross-sectional data. Bover uses a sophisticated instrumental variables methodology to estimate a marginal propensity to spend out of housing wealth in Spain of between 1 and 2 percent, a result that seems both robust and plausible. Bostic et al use pooled cross-sections merging CEX and SCF data. However, their parameter estimates grossly violate the basic presumption that if permanent labour income and assets both double, consumption should roughly double, which compromises their interpretability.

\section{Derivation of the Consumption Model}

The aim of this section is to derive an ECM for consumption with better foundations than equation (2.1) and other commonly used empirical specifications.

\section{(a) Theoretical foundations}

Since the seminal paper of Hall (1978), the permanent income hypothesis (PIH) for an infinitely-lived representative agent endowed with rational expectations (RE) has exerted a powerful influence on empirical work on consumption. Under a number of simplifying 
assumptions ${ }^{6}$ Hall derived a martingale property for the intertemporal efficiency condition on consumption, or the Euler equation:

$$
c_{t}=c_{t-1}+\varepsilon_{t}
$$

where $\varepsilon_{\mathrm{t}}$ is a stochastic variable, unpredictable from information dated $\mathrm{t}$ - 1 , capturing news about permanent income. Note that equation (3.1) embodies the extreme consumption smoothing implication of the PIH, since at $\mathrm{t}-1$, the consumer plans future consumption levels to be the same as the current level.

Solving this efficiency condition and its equivalents for all future periods and combining with the life-cycle budget constraint, gives the standard solved-out form of the consumption function

$$
c_{t}=r A_{t-1}+y_{t}^{P}
$$

where $y_{t}^{P}$ is expected permanent non-property income, $\mathrm{r}$ is the real rate of return, and $A_{t-1}$ is the real asset stock at the end of the previous period.

Although the Euler and solved-out consumption functions in the canonical REPIH model are theoretically equivalent, the empirical versions of equations (3.1) and (3.2) are not equally useful for three reasons. First, an explicit income-generating mechanism is needed to estimate equation (3.2). Second, unlike the Euler equation, the solved-out consumption function does not discard long-run information in the data on consumption, income and assets. The literature on 'equilibrium correction models' and cointegration, (e.g. Davidson et al, 1978; Engle and Granger, 1987; Johansen and Juselius (1990) and Banerjee et al, 1993) emphasizes the importance of extracting long-range information. In the Euler approach, the asset data are not used at all; and, by differencing, consumption and income, which are typically non-stationary, are reduced to stationarity. As we shall demonstrate, the impact of credit market liberalization on consumption is easier to capture using long-run information.

Third, the solved-out approach is directly relevant for policy analysis. For instance, the effects of a tax reform (which would alter the profile of future household income) could

\footnotetext{
${ }^{6}$ These include no credit restrictions or 'worst case scenarios' (Carroll, 1997,2001), quadratic utility, a given market real interest rate equal to the subjective discount rate, additive preferences (excluding habits and interactions with leisure), infinitely lived or Barro-style dynastic households, and rational expectations.
} 
be analysed via an income-forecasting model incorporated in the solved-out consumption function. Lastly, the approximations needed to obtain policy-relevant consumption functions of the type described in the next sections are no more extreme than those popularly made in the Euler equation context. Indeed, we agree with Carroll (2001a) that the traditional Euler approximations are quite limited.

\section{(b) A model for credit-unconstrained households.}

At the individual level, a solved-out consumption function is the solution to an intertemporal utility-maximizing problem, the case of the canonical REPIH, equation (3.2), being the classic example. We shall now extend equation (3.2), and begin by log-linearizing it. Dividing equation (3.2) by income gives

$$
\left.c_{t} / y_{t}=r A_{t-1} / y_{t}+y_{t}^{P} / y_{t}=r A_{t-1} / y_{t}+\left(y_{t}^{P}-y_{t}\right) / y_{t}\right)+1
$$

Noting that $\log (1+x) \cong x$, when $\mathrm{x}$ is small (from the first term of a Taylor expansion around $\mathrm{x}=0)^{7}$, that $r A_{t-1} / y_{t}$ is small for most consumers, and that $\left(y_{t}^{P}-y_{t}\right) / y_{t} \cong \log \left(y_{t}^{P} / y_{t}\right)$,

$$
\log c_{t}=\log y_{t}+r A_{t-1} / y_{t}+\log \left(y_{t}^{P} / y_{t}\right)
$$

One important advantage of equation (3.4) is to avoid the log assets formulation employed in many studies of consumption. This tends to be a very poor approximation when asset levels are low, as is true for many households. It is also a poor approximation when assets are disaggregated to test hypotheses on, for example, the marginal propensity to consume ( $m p c$ ) out of equity wealth versus housing wealth.

The difference between log permanent and log current income in (3.4) can be expressed as

$$
\log \left(y_{t}^{P} / y_{t}\right)=E_{t}\left(\sum_{1}^{k} \delta^{s-1} \log y_{t+s} / \sum_{1}^{k} \delta^{s-1}\right)-\log y_{t}=E_{t} \Delta \log y m_{t+k}
$$

where $\Delta \log y m_{t+k}$ is defined as a weighted moving average of forward-looking income growth rates, see Campbell (1997). To dynamise the static form of equation (3.4), for

\footnotetext{
${ }^{7}$ The approximation in equation (3.4) can be improved further by considering a second order Taylor expansion: $\log (1+x) \cong x-0.5 x^{2}$ and we implement this below.
} 
instance to introduce habits or adjustment costs, implies a partial adjustment form of equation (3.4), see Muellbauer (1988) for a rigorous derivation.

Further, extending the model to probabilistic income expectations, suggests the introduction of both a measure of income uncertainty, $\theta \mathrm{t}$, as well as allowing the discount factors in expected income growth, measured by $E_{t} \Delta \log y m_{t+k}$ to incorporate a risk premium, so discounting the future more heavily than by the real rate of interest, see Hayashi (1985). If real interest rates are variable, standard theory suggests the real interest rate $r_{t}$ enters the model, with the usual interpretation of inter-temporal substitution and income effects.

Incorporating income uncertainty and the real interest rate, and partial adjustment, a simple linearization gives the following generalisation of the canonical REPIH model in equation (3.2):

$$
\Delta \log c_{t} \approx \beta\left(\alpha_{0}-\alpha_{1} r_{t}-\alpha_{2} \theta_{t}+\log y_{t}+\alpha_{3} E_{t} \Delta \log y m_{t+k}+\gamma A_{t-1} / y_{t}-\log c_{t-1}\right)+\varepsilon_{t}
$$

where $\beta$ measures the speed of adjustment. In principle, the coefficients $\alpha_{3}$ and $\gamma$ should depend upon the real interest rate, $r_{t}$; they should also depend on $\theta_{t}$, since discount factors applied to expected incomes will increase with income uncertainty, as Skinner (1988), Zeldes (1989), and Carroll (1997, 2001b) have emphasized. For simplicity we will temporarily suppress this complication and the associated potential non-linearities. ${ }^{8}$

In practice, there are a number of reasons why income growth expectations embodied in $E_{t} \Delta \log y m_{t+k}$ are likely to reflect a limited horizon. With aggregate data it is difficult to forecast income beyond about 3 years. Indeed, widely used time series models have usually lost most of their forecasting power by then. This suggests that the log of income in the more distant future is best forecast in practice by near-term log-income plus a constant. Further, with anticipated credit constraints, under buffer-stock saving theory (see Deaton 1991, 1992), a shortening of horizons is suggested. Precautionary behaviour with uncertain 'worst case scenarios' also generates buffer-stock saving, see Carroll (2001b) who argues that plausible calibrations of micro-behaviour can give a practical income forecasting horizon of about 3 years - as Friedman $(1957,1963)$ himself suggested.

\footnotetext{
${ }^{8}$ In principle, the aggregate consumption function should also include effects arising from aggregation over subgroups when evolutions take place in distributions of wealth and incomes, see Muellbauer and Lattimore (1995) p.273-276, in life-expectancy and in social security provision. We suspect that, over the 1967-2005 period, the UK is less sensitive to such omissions than many countries, but it will be important to check the parameter stability of the wealth effects in both countries.
} 
Finally, there is the question of the relevant level of disaggregation of the term $A_{t-1} / y_{t}$. In Carroll's model, there is a single liquid asset, and cash on hand, consisting of current income plus the liquid asset, can have an $m p c$ as high as one third in calibrations for aggregate data (though this $m p c$ will vary both in cross-sections and time). Carroll's model would support a relaxation of the frequent practice of including only net worth, or aggregating all financial assets in consumption functions, by allowing liquid assets to enter separately. In our empirical model we generalize equation (3.6) by splitting assets into three types, discussed further below.

\section{(c) Aggregating credit-constrained and unconstrained consumption using conventional assumptions.}

Equation (3.6) refers to the behaviour of forward-looking households who do not face current credit constraints. However, it could reflect the behaviour of buffer-stock savers who bear in mind the risk of credit constraints, for example through the special role of liquid assets, the impact of uncertainty, and via a short time horizon. If most of the effect of credit constraints is anticipated in this way, then one could argue that most of the effects of liberalizing credit conditions would be embodied in (3.6). Indeed, Carroll (2001a) has been quite critical of the treatment of credit constraints in Euler equations by Hall and Mishkin (1982) and Campbell and Mankiw(1989, 1991), though, to be fair, Campbell and Mankiw justify their Euler equation model as much in terms of rule of thumb behaviour as in terms of credit constraints. Assuming that $\pi_{\mathrm{t}}$ is the consumption share of credit-constrained households, aggregate logconsumption is approximately given by

$$
\log c_{t} \cong \pi_{t} \log c_{t}^{c}+\left(1-\pi_{t}\right) \log c_{t}^{u}
$$

Where $c_{t}^{c}$ is the consumption of the credit-constrained and $c_{t}^{u}$ that of the creditunconstrained. In the Euler equation literature, a widespread assumption is that for the creditconstrained consumers, consumption equals non-property income:

$$
\log c_{t}^{c}=\log y_{t}^{c}
$$


If one adopts the same simple assumption, one can derive an aggregate solved out consumption function, modifying (3.6) to take into account the behaviour of those just spending current income. To derive this form of the aggregate consumption function, we can define $\phi_{1 \mathrm{t}}$ as the deviation of the log of average income of credit-unconstrained households from average log income, and $\phi_{2 t}$ as the corresponding deviation for credit-constrained households.

$$
\log y_{t}^{u}=\phi_{1 t}+\log y_{t}
$$

and

$$
\log y_{t}^{c}=\phi_{2 t}+\log y_{t}
$$

The further assumption that $\pi_{\mathrm{t}}$ as well as $\phi_{1 \mathrm{t}}$ and $\phi_{2 \mathrm{t}}$ evolve only slowly yields the following approximate expression ${ }^{9}$ for the growth rate of consumption:

$$
\begin{aligned}
\Delta \log c_{t} \approx \beta\left[\left(1-\pi_{t}\right) f\left(x_{t}\right)+\left[\left(1-\pi_{t}\right) \phi_{1 t}+\pi_{t} \phi_{2 t}\right]+\gamma A_{t-1} / e^{\phi_{t}} y_{t}+\log y_{t}-\log c_{t-1}\right] \\
+(1-\beta) \pi_{t} \Delta \log y_{t}+\left(1-\pi_{t}\right) \varepsilon_{t}
\end{aligned}
$$

where $f\left(x_{t}\right)=\alpha_{0}-\alpha_{1} r_{1 t}-\alpha_{2} \theta_{t}+\alpha_{3} E_{t} \Delta \log y m_{t+1}$.

\section{(d) Implications of credit market liberalization}

We now use equation (3.11) as a framework for analysing the consequences of credit market liberalization, thereby contrasting the Campbell-Mankiw approach with the buffer-stock saving approach of Deaton and Carroll. Much of the literature following Campbell and Mankiw (1989, 1991) has conceived of the effect of credit market liberalization as a reduction in the consumption share of the credit constrained, $\pi_{\mathrm{t}}$ in equation (3.6), with improved access to credit. However, the interpretation of equation (3.11) in which credit market liberalization works entirely through the consumption share of the credit constrained, has two quite implausible implications. The first is that after liberalization, increases in

\footnotetext{
${ }^{9}$ Note that equation (3.6) applies to households not currently credit constrained. The term in $\log c^{u}{ }_{t-1}$ therefore needs to be converted into observed $\log c_{t-1}$ and observed $\log y_{t-1}$ using equations (3.7) to (3.10) - see derivation details in the Appendix
} 
income uncertainty, $\theta$, have larger consumption effects. This is because the uncertainty term is weighted by $\beta(1-\pi)$ which rises as $\pi$ falls. Yet given the interactions between expected credit constraints and income uncertainty analysed by Deaton and Carroll, it seems more plausible to expect the opposite: with better access to credit, households can more easily borrow their way through temporary income short-falls or extra consumption needs, and therefore will be less affected by increased income uncertainty. On this view, few households are literally credit constrained in any quarter, so the main influence of better access to credit is on the buffer-stock savers in equation (3.6) rather than through changes in $\pi$.

The second implausible implication is that the long-run effects on the average propensity to consume are small and probably negative. The argument for this is simple, assuming that life-cycle households represented by equation (3.6) have a positive propensity to save. Since credit constrained households have a zero propensity to save, a fall in the share of such households therefore raises the saving rate, and lowers the average propensity to consume. However, the buffer-stock saving view suggests the opposite. There will be a reduction in the need for buffer-stock saving if easy access to borrowing can smooth consumption through temporary income reductions. To anticipate our later empirical findings for both the UK and South Africa, we find the $(1-\beta) \pi_{t} \Delta \log y_{t}$ term in (3.11) to be insignificant in both countries, while the role of uncertainty declines with the easing of credit conditions, favouring the buffer-stock interpretation of consumer behaviour of Deaton and Carroll.

We now move away from considerations of the effect of credit liberalization only through its impact on consumption smoothing, to develop a collateral view of liberalization. The effects for the average propensity to consume are then more dramatic. In most countries, most household debt is backed by collateral. The first point concerns young creditconstrained households saving for the minimum deposit required to get onto the owneroccupied housing ladder. ${ }^{10}$ Suppliers of mortgage credit set upper limits to loan-to-income and loan-to-value ratios to reduce default risk. Such households will consume less than income, the difference depending on the ratio of house prices to income and on the minimum deposit as a fraction of the value of the house. A reduction in credit constraints in the form of a reduction in the minimum deposit as a fraction of the value of the house, will raise the

\footnotetext{
10 Owner-occupation offers advantages in many societies, for example a preferred tax status, lower long-run costs than renting and the elimination of agency costs of landlords.
} 
consumption of these households relative to income (see Japelli and Pagano (1994) and Deaton (1999), and micro evidence in Engelhardt (1996)).

Most of these potential first-time buyers of housing are not credit-constrained in the sense of being unable to smooth consumption. The savings they are building up for a future housing deposit can be run down or increased in anticipation of shorter-term income fluctuations and in response to changes in real interest rates. Their behaviour is thus better approximated by a modification of equation (3.6), with an explicit direct positive effect of financial liberalization on consumption.

A second point in the collateral view, concerns those who already own collateral. In a number of countries, the relaxation of rules and spread of competition has made it easier to obtain loans backed by housing-equity (see Poterba and Manchester, 1989). A rise in house prices then makes it possible to increase debt or to refinance other debt at the lower interest rates given collateral backing. Effectively, the liberalization of credit conditions increases the "spendability" or liquidity of such previously illiquid housing wealth.

In countries where floating rate debt is important, indebted households can be subject to short-term shocks to cash flows when nominal interest rates change. Their consumption growth rate is thus likely to be influenced by changes in the debt service burden, which can be well represented by proportional changes in the nominal interest rate, weighted by the debt to income ratio. Better access to collateral will reduce the impact of such changes, as households with positive net equity can more easily refinance to protect cash flows against rises in nominal interest rates. The negative effect of nominal interest rate changes weighted by the debt to income ratio, should thus weaken with credit market liberalization.

\section{(e) The empirical specification}

The above discussion emphasizes the likely importance of disaggregating assets. First, buffer-stock theory suggests there should be a larger weight on liquid assets in consumption. Otsuka (2006) ch.2, has provided rigorous micro-foundations for this conclusion by analyzing a model with liquid and illiquid assets and a credit constraint. ${ }^{11}$ Illiquid assets incur transactions costs, making liquid assets part of the buffer-stock hedging against shortterm income uncertainty, even though illiquid assets have a higher return. Liquid assets are the first marginal source for spending in temporary income down-turns. Second, the collateral

\footnotetext{
${ }^{11}$ We are grateful to Chris Carroll for pointing us to this reference.
} 
view developed above suggests there will be shifts in the "spendability" of housing and other illiquid wealth with credit market liberalization. ${ }^{12}$ Thus, wealth effects on consumption will differ according to the liquidity characteristics of different types of wealth, and these characteristics shift with liberalization.

Households usually hold a balance of assets, liquid assets, which can easily be converted into expenditures when needed, and illiquid assets, which typically yield higher rates of return. Housing, pension funds, and life insurance funds are at the illiquid end of the spectrum. Pension wealth is likely to have a delayed impact on consumption. Contractual saving contribution rates often respond with considerable lags to changes in the asset values of such pension funds, suggesting that we should allow for longer lags on consumption.

Housing wealth is a special case because housing has consumption value as well as wealth value (note that housing services also appear in the utility function). Thus, an increase in the real price of housing has both an income and a substitution effect on consumption, partly offsetting the wealth effect. See Miles $(1992,1994)$, and, for a simple derivation, see Muellbauer and Lattimore (1995). Moreover, the increased access to collateral as housing wealth rises is probably the most important effect of housing wealth on consumption in economies with liberal credit markets. House price rises in illiberal credit markets where large down-payments are required could well result in an overall negative effect of housing wealth on consumption. This is because increased saving for a housing down-payment combined with negative income and substitution effects on consumption could more than offset the wealth effect for the owners.

As there are lumpy transactions costs in housing, it is possible that wealth or collateral effects will depend not only on the previous period's value of housing wealth, but also on consumers' expectations of the growth rate of house prices over the near term future. In our empirical work we represent this by the 4-quarter forecast rate of appreciation of real house prices weighted by the lagged housing wealth to income ratio or, under the hypothesis that households cannot forecast house prices well, by the previous quarter's rate of appreciation similarly weighted. But, as it emerges, this effect is not significant in either country.

In the light of the preceding discussion, we propose the following econometric model that generalises equation (3.11) in four respects. First, it disaggregates the net worth to income ratio into three elements: the ratio of liquid assets minus debt to non-property income

12 Several studies, such as Patterson (1984), allow different weights on liquid and illiquid assets, whereas others, such as Zellner, Huang, and Chau (1965) and Hendry and von Ungern Sternberg (1981), include the effects of liquid assets alone. 
(NLA/y), the ratio of illiquid financial assets to non-property income (IFA/y), and the ratio of housing wealth to non-property income $(\mathrm{HA} / \mathrm{y})$. Second, it allows for the direct effect of credit market liberalization on the average propensity to consume and for many parameters to shift with liberalization. Third, it adds a term in the debt to income weighted growth rate of nominal borrowing rates (nr).

The model that develops equation (3.11) with these factors is

$$
\begin{aligned}
& \Delta \log c_{t} \approx \alpha\left[\begin{array}{l}
\alpha_{0 t}-\alpha_{1 t} r_{t}-\alpha_{2 t} \theta_{t}+\alpha_{3 t} E_{t} \Delta \log y m_{t+k}+\gamma_{1} N L A_{t-1} / y_{t}+\gamma_{2} I F A_{t-1} / y_{t}+\gamma_{3 t} H A_{t-1} / y_{t} \\
+\log y_{t}-\log c_{t-1}
\end{array}\right] \\
& +\beta_{1 t} \Delta \log y_{t}-\beta_{2 t}\left(D B_{t-1} / y_{t}\right) \Delta \log n r_{t}+\varepsilon_{t}
\end{aligned}
$$

It is important to note that this equation satisfies long-run homogeneity in income and assets: doubling both, doubles consumption. The long run coefficient on $\log \mathrm{y}$ is 1 . This means that the income endogeneity issues which Hall (1978) highlights are not of concern for the measurement of the long-run income and asset effects: variations in asset to income ratios are dominated by movements in lagged asset prices, so that the endogeneity of income is practically irrelevant. For the estimation of the short-term income coefficient $\beta_{1 t}$, and the speed of adjustment $\alpha$, there could be more of an issue, see below.

The time subscripts on the various parameters indicate that many parameters will shift with credit market liberalization. In order, $\alpha_{0}$ rises reflecting mainly reduced saving for a housing down-payment - the direct effect of liberalization; $\alpha_{1}$ and $\alpha_{3}$ rise reflecting increased intertemporal substitution; $\alpha_{2}$ falls because of reduced concern with income uncertainty; $\gamma_{3}$ rises with increased access to housing collateral; $\beta_{1}$ falls because of fewer credit constrained households or a reduced weight on current income; $\beta_{2}$ falls because increased access to finance allows households to overcome temporary cash flow constraints from higher nominal rates.

In general, there are few satisfactory measures of credit market liberalization. For the UK we can use the scalar credit conditions index CCI estimated by Fernadez-Corugedo and Muellbauer (2006) (F-C M), to permit these parameters to vary. In South Africa, we estimate it jointly from consumption and debt equations, given institutional information about the timing of credit market liberalization.

\section{Empirical Results for the UK}




\subsection{Wealth Data}

The wealth data for the UK household sector come from the Office of National Statistics. We group assets into three components, the first being net liquid assets defined as liquid assets (or household M4) minus household debt, including both consumer credit and mortgage debt. The second component, illiquid financial assets, consists of holdings of bonds and shares, including mutual funds, and pension assets. The third is housing wealth (for details on this and the other income and wealth data, see variable definitions in Table 2, and F-C M). Figure 1 plots log consumption/income against housing assets/income and illiquid asset/income, where assets are measured at the end of the previous quarter, and income is non-property disposable income.

\subsection{Credit Conditions Index}

For the UK, we use the consumer credit conditions index, CCI, derived by FernandezCorugedo and Muellbauer (2006). It is widely perceived that credit supply conditions faced by U.K. consumers, particularly in the mortgage market, have been liberalised since the late 1970s, with implications for the housing market and consumer spending. This paper examines quarterly micro-data from the Survey of Mortgage Lenders (SML) to learn about changes in credit conditions from loan-to-value ratios (LVRs) and loan-to-income ratios (LIRs) of first-time buyers (classified by region and age). It combines data on the proportions of high LVR and high LIR loans with aggregate information on U.K. consumer credit and mortgage debt to give ten quarterly series for 1975-2001. These are modeled in a ten-equation system. A comprehensive set of economic and demographic influences on the demand and supply of credit, applying relevant sign restrictions, are controlled for, including an uncertainty factor common to all ten equations. A single time-varying index of credit conditions captures the common variation in the ten credit indicators purged of the economic and demographic controls. In the extension of the data to 2005, we assume no change in the index after 2001 and splice it to the index estimated in Muellbauer (1997) before 1976. The index, shown in Figure 2, increases in the 1980s, peaking towards the end of the decade and again towards 2001 .

\subsection{The Income-forecasting Equations}


The dependent variable in the income forecasting equation, $\Delta \log y p e r m$, is defined as the difference between 'log permanent' and log current income given by (3.5), where the discount factor is 0.85 and the horizon $\mathrm{k}$ is 3 years, as originally suggested by Friedman (1963), see Carroll (2001) for discussion. With a discount value of 0.85 , truncating the geometric formula for permanent income after 12 quarters introduces only a slight approximation error. To forecast $\Delta \log$ yperm, we examined a range of alternative informational assumptions. At one extreme, we regress it simply on $\Delta \log \mathrm{y}$ and its lags, which would be the reduced form of an AR process in $\Delta \log \mathrm{y}$. However, we allow for the possibility of longer lags by considering also $\Delta_{4} \log$ y at lags of 4 and 8 quarters. The only significant lag is a negative effect at lag 8 , suggesting some kind of reversion in growth rates, but this is not a very stable relationship. The next simplest is to introduce a trend and the level of $\log \mathrm{y}$. This suggests strong trend reversion, with some persistence in the annual growth rate, and fits better. We use it to generate a 'naïve' forecast.

At the other extreme, we posit a long-run relationship for $\log \mathrm{y}$ as a function of a linear trend $(+)$, real interest rates $(-)$, the logs of real oil prices $(-)$, share prices $(+)$ and real house prices $(+)$, the rate of taxes on income $(-)$, the rate of unionization $(+)$ since greater union power should raise the share of labour income, and some national accounts ratios. These include the ratio of the government surplus to GDP where a higher ratio in the long run should allow lower tax rates or higher government spending, though offset in the short run by the negative 'Keynesian' effect of fiscal contraction, and the ratio of the trade deficit to GDP, since trade deficits have in the past constrained growth. However, there was a profound shift in fiscal policy around 1980, with the coming into power of the Thatcher government. This would be expected to have reinforced the positive role of the government surplus, and with the Burns-Lawson doctrine ${ }^{13}$, to have led to trade deficits no longer mattering for fiscal policy. We find strong evidence for both hypotheses by testing for interaction effects with pre and post 1980 dummies. We also test for a shift in the early 1980s in the role of real house prices, to be consistent with the shifting role of housing wealth in consumption with credit market liberalization outlined in section 3(d) above. We confirm the absence of a

\footnotetext{
${ }^{13}$ The doctrine states that with free global capital flows, governments should not concern themselves budget deficits, but not with trade deficits and let these be a matter for the private sector. Terence Burns as chief economic advisor and Nigel Lawson as chancellor, made the doctrine official policy. Exchange controls were removed in 1979.
} 
positive real house price effect on income before the early 1980s. We also checked for world growth and real exchange rate effects but failed to find stable relationships.

The long run level effects discussed all enter as 4-quarter moving averages, though for oil prices, the lags are even longer. Using a general-to-specific reduction procedure, using HAC t-ratios and F-tests, we check for short run dynamics from changes in interest rates, where negative effects are confirmed, and growth rates of income and real oil and asset prices, in part to check for dynamic mi-specification due to the choice of 4-quarter moving average level effects. ${ }^{14}$ We also investigated specification between these two extremes, for example, with trend reversion, interest rates and asset prices and no other variables. These also confirm that house price effects only begin to matter in the $1980 \mathrm{~s}$.

\subsection{The Consumption Equation}

We analyse data for 1967-2005 for two alternative definitions of consumer credit. ${ }^{15} \mathrm{We}$ begin with the specification by Case et al (2005). All models include intercepts, seasonals, a $+/-1$ dummy for the advancement effect of the 1979 introduction of VAT, similar advancement effects in 1968 Q1 and 1973 Q and a measure of the change in long-duration strikes $^{16}$. The results are shown in column 1 of Table 3 . The model shows jointly significant but individually insignificant wealth effects, significant short-term but no long-run income effects. The point estimates suggest that the elasticity of consumer spending with respect to real housing wealth is around five to eight times as large as that of illiquid financial wealth, and that after 1986, consumption growth responded more to housing wealth than before. Repeating the estimation using personal disposable income including property income, still leaves the long-run effect of income insignificant.

Next we estimate a version of equation (3.11) assuming all coefficients are constant and omitting any role for credit market liberalization. We find that both for the UK and for South Africa, a 4-quarter moving average of observations on illiquid financial assets fits far

\footnotetext{
${ }^{14}$ Details of these models are available on request.

${ }^{15}$ The consumer credit data are published only from 1976. Under one assumption we use total household debt minus mortgage debt as a proxy for consumer credit for the whole period. Under the other, we splice nonmortgage debt to the published consumer credit data in 1976 to generate the pre 1976 data. Non-mortgage debt includes a good deal of small business borrowing, and so is not quite ideal to model household behaviour. In the event, the key parameter estimates are hardly affected by which choice is made, and we report results for the second assumption.

${ }^{16}$ The strike indicator is the lagged change in the number of working days lost through strikes, which appears to have temporary effects on consumption, see Muellbauer and Murphy (1995).
} 
better than the end of previous quarter value, consistent with findings by Lettau and Ludvigson (2004). ${ }^{17}$ Since much of illiquid financial assets in the UK is in pension funds, this plausibly reflects the slow adaptation of contribution and pay-out rates to changes in asset values. We also find that in both countries, the real interest rate is better represented by the 4quarter moving average than by the current quarter's value, while the annual log change of the nominal rate is preferable to the quarterly rate. The model takes the following form (see Table 2 for further details on variable definitions). Note that the extra term in the Taylor expansion has been included to improve the approximation, see above equation $(3.4)^{18}$. The dummies and the strike indicator mentioned above are also included.

$$
\begin{aligned}
\Delta \log c_{t}= & \alpha\left[\left(\alpha_{0}+C C I\right)+\left(\alpha_{1}+\alpha_{1 c} \times C C I\right) r m a_{t}\right. \\
& +\left(\alpha_{2}+\alpha_{2 c} \times C C I\right) \theta_{t}+\alpha_{2 c c} \theta^{*}+\left(\alpha_{3}+\alpha_{3 c} \times C C I\right) E_{t} \Delta \log y_{t} e r m_{t+12} \\
& +\gamma_{1} N L A_{t-1} / y_{t}+\gamma_{2} I F A m a_{t-1} / y_{t}+\left(\gamma_{3}+\gamma_{3 c} \times C C I\right) H A_{t-1} / y_{t} \\
& -0.5\left(\gamma_{1} N L A_{t-1} / y_{t}+\gamma_{2} I F A m a_{t-1} / y_{t}+\left(\gamma_{3}+\gamma_{3 c} \times C C I\right) H A_{t-1} / y_{t}\right)^{2} \\
& \left.+\log y_{t}-\log c_{t-1}\right] \\
& +\left(\beta_{1}+\beta_{1 c} \times C C I\right) \Delta \log y_{t}+\left(\beta_{2}+\beta_{2 c} \times C C I\right)\left(D B_{t-1} / y_{t}\right) \Delta_{4} \log n r_{t} \\
& + \text { dummies }+\varepsilon_{2 t}
\end{aligned}
$$

These results are shown in column 1 of Table 4 . The fit is much improved compared to the Case et al specification, and the speed of adjustment rises to 0.27 , consistent with significant long-run income and wealth effects. While the estimated marginal propensity to spend out of liquid assets minus debt is quite high at 0.15 , that out of illiquid financial wealth is estimated at 0.033 and that out of housing wealth 0.041 . In terms of dynamics, the effects of the fourquarter change in the unemployment rate and the debt weighted four-quarter rate of change of nominal interest rates are both negative and strongly significant. The effect of forecast income growth is significant and suggests a weight on future income of 0.45 (and so 0.55 on current income). The rate of change of income is not significant and hence is deleted from the model. ${ }^{19}$ The real interest rate effect is negative but completely insignificant.

\footnotetext{
${ }^{17}$ However, Lettau and Ludvigson understate the empirical significance of the stock market effect over one or two year horizons.

${ }^{18}$ A second order Taylor expansion, $\log (1+x) \cong x-0.5 x^{2}$ suggests including the assets term:

$-0.5\left(\gamma_{1} N L A_{t-1} / y_{t}+\gamma_{2} \text { IFAma }_{t-1} / y_{t}+\left(\gamma_{3}+\gamma_{3 c} \times C C I\right) H A_{t-1} / y_{t}\right)^{2}$.

19 Endogeneity bias cannot plausibly account for this finding, since common shocks to income and consumption should bias up the short-term income effect. Measurement error could account for a bias towards zero. Attempts to instrument the growth rate of income did not change the conclusions, however. Replacing current income by a weighted average of current income and the 4-quarter moving average, both in the level and the rate of growth,
} 
We now add the credit conditions index of F-C M, though playing only an intercept role. It is strongly significant $(\mathrm{t}=2.8)$ and raises the speed of adjustment, see column 2 . Now the real interest rate effect is negative and significant. The long-run illiquid wealth effects are broadly similar to those in column 1: the marginal propensity to spend out of net liquid wealth is estimated at 0.19 , out of illiquid financial wealth at 0.031 and out of housing wealth at 0.037 , the last two being somewhat lower than when CCI is omitted. Among the dynamic effects, forecast income growth is still strongly significant. The changes in the unemployment rate and in debt-weighted nominal interest rates remain strongly significant. However, the change in current income is still irrelevant, consistent with the buffer-stock saving hypothesis.

Next, we estimate the fully general version of equation (4.1) allowing all the coefficients potentially varying with credit conditions to do so. While this is clearly too general a model to expect all the hypothesized interaction effects to be significant, no coefficient significantly violates the hypothesized sign priors. The same is true over subsamples 1967-95, 1970-2005, 1976-2005. Further, even in the general model, three striking interaction effects stand out: the shift in the forecast income growth term with CCI, the weakening of the negative debt weighted nominal interest rate effect with CCI and most important of all, the rise in the housing wealth coefficient with CCI. Indeed, the hypothesis that the housing wealth effect is zero when CCI is zero is easy to accept. This is consistent with the emphasis of Aoki et al (2004) on the collateral role of housing wealth in releasing credit constraints. The $m p c$ out of net liquid assets is now 0.13 , out of illiquid financial wealth 0.024 , and 0.032 out of housing wealth at the peak values of the credit conditions index.

Given that income growth expectations and their interaction with CCI are about equally significant, and the same is true for the real interest rate and its interaction, it is interesting to examine the specification in which only the two interaction effects are retained. The coefficient on the interaction of expected income growth and CCI is then estimated at 2.81 , implying that at the peak of CCI of 0.25 , the weight on future expected income is 0.7 relative to 0.3 on the current quarter's income. The fact that the weight on current income is 0.7 , instead of 0.85 , assumed in the construction of $\Delta \log y$ perm, suggests that some households just take current income as proxy for future income. It certainly does not

suggested a zero weight on the moving average term. Repeating these exercises in the context of columns 2 and 3 strengthened the conclusion that the rate of growth of income has an insignificant effect in the context of this model. 
contradict the choice of a discount factor consistent with a relative short horizon. Estimation of the model over different samples suggests that parameter stability is very satisfactory.

Experimenting with differing specifications of the income growth forecasting equation affects the coefficients on expected income growth and on housing wealth, but tends to have less influence on the other coefficients. For example, the naïve specification discussed above raises the coefficient on expected income growth at the CCI peak from 0.57 to 0.85 , and the $m p c$ out of housing wealth at the CCI peak from 0.032 to 0.05 , but leaves both financial asset effects almost unchanged, while the equation standard error rises only slightly. The reasons are clear enough: if one argues that house prices have a partly expectational role and includes their effect in the income forecasting equation, then the pure wealth or collateral effect on spending is necessarily smaller. If, at the other extreme, one attributes no expectational role to house prices, then the wealth or collateral effect is larger. Unfortunately, it seems that goodness of fit does not discriminate between the alternative views without direct survey evidence on income expectations.

The model in which CCI plays only an intercept role is linear and can be interpreted in terms of co-integrated variables. Effectively, the log ratio of consumption to non-property income and the three asset to income ratios form a co-integrated relationship between four I(1) variables, subject to a shift in the intercept via CCI. Since the real interest rate is arguably I(0) and in any case plays only a marginal role, we can neglect it here. We carried out a co-integration analysis, in which we treat CCI as an exogenous shift dummy, and include in the equation system I(0) variables such as income growth and the change in the unemployment rate and the impulse dummies, but outside the co-integration space. With a lag of three, there appear to be two co-integrating relationships. One is close to the long-run solution implied by the column 2 estimates. The other has no obvious economic interpretation. $^{20}$

The apparent breakdown in the bivariate relationship between real house prices and consumption since 2000 has been the subject of comment from the Bank of England ${ }^{21}$ and has been accompanied by a significant break-down in the Bank's new model, see Benito et al (2006). Our model suggests that a substantial part of the earlier correlation was due to variation in common causal factors including income, interest rates, unemployment and credit conditions. Since 2000 , the fall in stock market prices, together with the continuing fall in

\footnotetext{
${ }^{20}$ Details are available on request.

${ }^{21}$ See, for example, minutes of the Monetary Policy Committee meeting held on 8-9 February 2006, paragraph 9 and Minutes of Evidence by Mervyn King to the Treasury Select Committee, 30 ${ }^{\text {th }}$ November 2004.
} 
net liquid assets due to the rise in debt, while house prices continued to rise strongly, explains why consumption growth has been far weaker than real house price growth. The decline of the net liquid asset to income ratio, given the large spending propensity associated with net liquid assets, suggests that UK consumption has become more vulnerable than previously to a fall in asset prices.

\section{Empirical Results for South Africa}

\subsection{Wealth Data}

Neither the central bank nor other government statistical agencies in South Africa publish balance sheet wealth estimates on a market value basis, of the type produced by U.S. Federal Reserve Board, the Bank of England and the Office of National Statistics in the U.K., and now also by a few emerging market countries, such as Hungary, Mexico and Poland (see OECD, 2004). With some difficulty, it is possible to derive estimates for South Africa from existing data. ${ }^{22}$ The wealth estimates on a market value basis used in this paper were constructed in Aron and Muellbauer and Aron (2006), and are the first systematic attempt to construct such figures for South Africa ${ }^{23}$.

There were two main problems in deriving these wealth estimates for the personal sector. Most asset data published by the South African Reserve Bank (SARB) are on a bookvalue and not on a market-value basis, and required revaluation adjustments using appropriate asset price indices. Secondly, for some asset classes, e.g. official pensions and directly-held bonds, the SARB publish only flow-of-funds data and no benchmarks. Appropriate estimates of the relevant benchmarks needed to be made, and the flows of funds data cumulated, and, where necessary, revalued to market prices. Further, there are problems of omission of some wealth components. ${ }^{24}$ Nevertheless, the assets and debts included in our

\footnotetext{
${ }^{22}$ While wealth estimates on a market value basis are not published, the SARB has published flow of funds data back to 1970, as well as information on households' holdings of local authority and public enterprise bonds, unit trusts (mutual funds), pension and long-term insurance funds, using a mix of book values and market values, and household debt data. From these data and other sources, it is possible to assemble a profile back to 1970 of the main components of household sector assets and debts.

${ }^{23}$ This work has since been extended in collaboration with the SARB (see Aron, Muellbauer and Prinsloo, 2006a and 2006b). These data will in due course be regularly published by the SARB in aggregate form, back to 1975 .

${ }^{24}$ The SARB has not attempted estimates of gold and foreign assets held by the personal sector. Despite exchange controls, progressively relaxed since 1995 , there were inevitable loopholes, suggesting a significant undercounting of asset ownership. Non-housing assets owned by unincorporated businesses, and ownership of
} 
estimates are measured with reasonable accuracy and are likely to be the main components of wealth relevant for consumer spending and portfolio decisions of South African households.

The estimates of illiquid and liquid personal wealth are shown in Figure 5. The household liquid assets ratio seems to have been relatively stable in the 1970s. In the 1980s, however, households' holdings of liquid assets relative to non-property income fell sharply. ${ }^{25}$ This coincided with both a drop in the personal saving ratio, as implied by the income and expenditure accounts, and a switch to saving in pension and retirement funds offering superior returns to those on liquid assets.

Pension wealth has grown relative to income since the 1980s, exceeding the growth of debt. ${ }^{26}$ Pension wealth is now the single biggest asset, given the decline of housing wealth relative to income (which has only been reversed in recent years).

\subsection{Financial Liberalization}

An indicator of credit market conditions, CCI, is required to drive the direct, positive effects on consumption; the "spendability" weights of asset components; and other possible interaction effects, for example with income uncertainty and income growth. Proxying CCI by the ratio of debt to income, as in Bayoumi (1993a, 1993b) and Sarno and Taylor (1998), is not ideal because this ratio responds with a lag to deregulation and depends too on income expectations, asset levels, uncertainty, and interest rates. Bandiera et al (2000) propose the technique of principal components to summarize the composite information in a set of dummy variables reflecting different facets of financial liberalization. However, the weights

corporations not publicly quoted on the stock exchange are also excluded. A third problem concerns the relationship between explicit funding of pensions and perceived entitlements, particularly for public sector pensions. There could have been considerable fluctuations in the relationship between recorded pension wealth and the perceived levels relevant for expenditure decisions. This problem is not unique to South Africa, however.

${ }^{25}$ Financial liberalization from 1983 into the 1990 s is partly responsible for the decline, as it reduced the precautionary, buffer-stock and consumption smoothing motives for holding liquid assets, see Deaton (1992). Political credibility effects probably induced currency substitution away from domestic assets and toward illegal foreign assets, especially after 1976 until the democratic elections of 1994. However, the main factor is the negative real after-tax return on liquid assets from the early 1970s to the early 1990s - apart from a brief spell in 1984-5 (see Prinsloo, 2000, p.17). Higher returns help explain the renewed rise in the liquid asset to income ratio from the late $1990 \mathrm{~s}$.

${ }^{26}$ Much of the rise in the $\log$ ratio of pension assets to income can be explained by a weighted average of total returns indices for equities and bonds. However, there are other factors, including the relaxation of restrictions on official pension funds (for government employees), which had prevented their holding of equities (Mouton Report 1992); improvement in the returns on government and parastatal bonds with deregulation of interest rates after 1980 and declining inflation in the 1990s; and relaxation of prescribed holdings of government bonds for all pension funds. Tax incentives have also favoured investment in pensions over directly held financial securities. 
do not reflect the behavioural impact of financial liberalization. A flexible technique linking institutional information with behavioural responses is needed.

Our innovation is to treat financial liberalization as an unobservable indicator entering both household debt and consumption equations. The indicator, CCI, is proxied by a linear spline function, and the parameters of this function are estimated jointly with the consumption and debt equations (subject to cross-equation restrictions on the coefficients in the spline function $)^{27}$.

The government initiated financial liberalization following the de Kock Commission reports $(1978,1985)$ advocating a more market-oriented monetary policy. Interest and credit controls were removed from 1980, and banks' liquidity ratios were reduced substantially between 1983 and 1985. However, there may have been a temporary reversal after the third quarter of 1985 as a result of South Africa's international debt crisis, when net capital inflows dropped sharply. Competition intensified in the mortgage market following the 1986 Building Societies Act, and amendments to the Act in 1987-88. Demutualization and takeovers in 1989-90 consolidated the stronger competition in the credit market. In the 1990s pensions were increasingly used to provide additional collateral for housing loans; while from 1995, special mortgage accounts ("access bond accounts") allowed households to borrow and pay back flexibly from these accounts up to an agreed limit set by the value of their housing collateral. After the 1994 elections more black South Africans obtained formal employment, particularly in the public sector, gaining access to credit that they may previously have been denied. ${ }^{28}$ Exchange controls on non-residents were eliminated in early 1995: large nonresident capital inflows from mid-1994 induced a temporary endogenous financial liberalization. Finally, exchange controls on domestic residents, in existence since before the 1960s, were partially relaxed after 1997.

This qualitative portrait has implications for our univariate measure of financial liberalization, $\mathrm{CCI}{ }^{29}$ The first is of a monotonic rise in the indicator: that is, no reversals, with the possible exception of a temporary episode after the debt crisis in late 1985, see above. The second is for particularly strong rises in 1981-84, from 1986, some consolidation in the early 1990s, and a renewed rise after 1994. Unfortunately, available information on institutional changes does not permit further quantitative implications to be drawn.

\footnotetext{
27 Had information on credit indicators such as mortgage loan to value and loan to income ratios, as in F-C M, been available, the equation system could have been extended.

28 Note, however, that total formal employment continued to decline.

29 A more detailed account of financial liberalization in South Africa is contained in Aron and Muellbauer (2002b).
} 
We define $C C I$ using a linear spline function. Define a dummy, D, which is zero up to 1980Q4 and is 1 from 1981Q1. The 4-quarter moving average, DMA81, then takes the values $0.25,0.5,0.75$ and 1 in the 4 quarters, respectively, of 1981, and the value 1 thereafter. We define DMA82 to be the 4-quarter lag of DMA81, and define DMA83 to DMA03 to be the corresponding 8- to 88-quarter lags of DMA81. We then define the spline function:

$$
C C I=d 81 \times D M A 81+d 82 \times D M A 82+\ldots+d 03 \times D M A 03
$$

where up to 23 parameters (i.e. d81 to d03) are estimated. The "knots" in the spline function occur in the first quarter of each year (i.e. it can shift shape in the first quarter of each year). Under the constraint that the parameters be non-negative (i.e. that there is no reversal in financial liberalization), except in 1985-86, in practice only six parameters are needed to define the CCI in an estimation from 1971Q1 to 2003Q4.

The estimated parameters for $C C I$ in the model reflect the key institutional changes in credit markets. Our estimated indicator shows strong rises from the early 1980s until just before the debt crisis of 1985, in 1988-89 and from 1993-95. (Figure 5). Interestingly enough, there is no sign of further liberalization after 1996, when CCI has reached its peak value of 0.27. It is noteworthy that both the consumption function and debt equation are subject to major structural breaks (failing Chow tests) when allowance is not made for financial liberalization.

\subsection{The Income-forecasting Equation}

During the 1980s in South Africa, there were significant regime changes with the move to new operating procedures for monetary policy and a series of internal financial liberalizations. Periodically, serious political crises entailed the increasing international isolation of South Africa, reflected in diminished trade and finance, while its mineral dependency as a primary exporter gives an important role to terms of trade shocks in determining income growth.

We derive a forecasting model for the rate of growth of real per capita disposable non-property income, $\Delta \log$ yperm, as defined in equation (3.5). We build in allowances for these features as well for a more standard income-expenditure approach for analysing the deviations of income from trend. Split trends are used to represent long-run changes in productivity growth of the kind one might expect in an economy subject to such regime 
changes. Further, an institutional measure of the shift in monetary policy in the early 1980s is crossed with the interest rates (for details see Aron and Muellbauer, 2002a.). By incorporating important regime shifts in the model, the consumption function including these income growth forecasts should be fairly immune to the Lucas critique (Lucas, 1976).

The model has the following form:

$$
\Delta \log \text { yperm }_{t+12}=\alpha_{0}+\text { Split }_{t}+\alpha_{1} \log y_{t}+\sum_{i=2}^{n} \alpha_{i} X_{i t}+\sum_{j=1}^{n} \sum_{s=0}^{k} \beta_{j} \Delta X_{j t-s}+\varepsilon_{t}
$$

where $\mathrm{y}_{\mathrm{t}}$ is real per capita disposable non-property income; Split $\mathrm{t}_{\mathrm{t}}$ are split trends reflecting the underlying capacity of the economy to produce and to sustain personal incomes; and the $\mathrm{X}_{\mathrm{jt}}$ include a range of possible determinants of income, discussed below.

This equation can be reformulated as an equilibrium correction formulation with a long-run solution given by

$$
\log y=-\left(\alpha_{0}+\text { Split }+\sum_{i=2}^{n} \alpha_{i} X_{i}\right) / \alpha_{1}
$$

The broad set of explanatory variables $X_{j}$ included the level of real interest rates and changes in nominal interest rates, the government surplus to GDP ratio, capacity utilization (as a proxy for the unemployment rate), terms of trade, a measure of trade openness, the real exchange rate, changes in the nominal rate, the growth rate of OECD industrial production, domestic credit growth in South Africa, real house prices and a real stock market price index. The model also captures the changing sensitivity of income growth to interest rates as the monetary policy regime changed, by employing a dummy indicator constructed from the changing prescribed liquid asset requirements for commercial banks in the 1980s, see Aron and Muellbauer (2002a). Income in the form of $\Delta \log$ yperm is modelled ${ }^{30}$ on quarterly data for 1972-2001, though with a restricted lag structure. For lags longer than three, we restrict the dynamics to fourth differences or four-quarter moving averages, to prevent overparameterisation. 


\subsection{The Consumption Equation}

In Section 3, we explained the various extensions required to the aggregate consumption equation (3.11) to incorporate different aspects of financial liberalization, a range of weights for different types of assets, and the argument that many credit-constrained households do not only spend current income.

We analyse quarterly data for 1971-2003, constrained by the availability of wealth stock data. Figure 4 plots log consumption to income and log debt to income ratios, where income is non-property disposable income. Before turning to an explicit model incorporating these features, two income measurement issues should be considered.

First, although self-employment is part of the theoretical definition of non-property income, these data are not separately available in the South African national accounts. The real, per capita, non-property income measure, $y$, consists of tax-adjusted income from employment and transfers from the government. We assume self-employment (a major component of property income in other countries) is highly correlated with property income in South Africa. If tax-adjusted, self-employment income were a constant fraction $\varphi$ of property income, $y^{\text {prop }}$, we could replace $y$ by $y+\varphi y^{\text {prop }}=y\left(1+\varphi y^{\text {prop }} / y\right)$. In our logformulation, this suggests $\left(y^{\text {prop }} / y\right)$ as an additional regressor.

The second issue concerns the measurement of real, per capita, non-property income, $y$. In constructing quarterly national income accounts, small timing discrepancies may arise between quarters, particularly in tax payments. Replacing current income $\log y_{t}$ by a weighted average of current and last quarter's recorded income e.g. $\lambda \log y_{t}+(1-\lambda) \log y_{t-1}$ or a 4-quarter moving average of income, it was found that $\lambda=1$, simplifying the empirical specification, as for UK data.

The resulting consumption equation, corresponding to equation (3.11), takes the following form (see Table 2 for variable definitions). Note that the extra term in the Taylor expansion has been included to improve the approximation, as in the UK equation (4.1). Various dummies are included. ${ }^{31}$

\footnotetext{
${ }^{30}$ The computations were performed in Hall, Cummins and Schnake's Time Series Processor (TSP 4.5) package and PCGETS (http://www.oxmetrics.com/).

${ }^{31}$ To simplify the expression we exclude details of the dummies from this equation. The dummies are Q1DU75, Q4, GST, GST84 and DSOWETO. Note that Q1DU75 is a pre-1976 seasonal to reflect mis-measured seasonal correction in the data before that date while Q4 is a seasonal. GST78 and GST84 are temporary dummies taking
} 


$$
\begin{aligned}
\Delta \log c_{t} & =\alpha\left[\left(\alpha_{0}+C C I\right)+\left(\alpha_{1}+\alpha_{1 c} \times C C I\right) r m a_{t}\right. \\
& +\left(\alpha_{2}+\alpha_{2 c} \times C C I\right) \theta_{t}+\left(\alpha_{3}+\alpha_{3 c} \times C C I\right) E_{t} \Delta \log \text { yperm }_{t+12}+\alpha_{4}\left(y^{\text {prop }} / y\right)_{t} \\
& +\gamma_{1} N L A_{t-1} / y_{t}+\gamma_{2} \text { DHIFAma }_{t-1} / y_{t}+\gamma_{2} P A m a_{t-1} / y_{t}+\left(\gamma_{3}+\gamma_{3 c} \times C C I\right) H A_{t-1} / y_{t} \\
& -0.5\left(\gamma_{1} N L A_{t-1} / y_{t}+\gamma_{2} \text { DHIFAma }_{t-1} / y_{t}+\gamma_{2} \text { PAma }_{t-1} / y_{t}+\left(\gamma_{3}+\gamma_{3 c} \times C C I\right) H A_{t-1} / y_{t}\right)^{2} \\
& \left.+\log y_{t}-\log c_{t-1}\right] \\
& +\left(\beta_{1}+\beta_{1 c} \times C C I\right) \Delta \log y_{t}+\left(\beta_{2}+\beta_{2 c} \times C C I\right)\left(\text { debt }_{t-1} / y_{t}\right) \Delta_{4} \log n r_{t} \\
& + \text { dummies }+\varepsilon_{1 t}
\end{aligned}
$$

This equation corresponds closely to the theory discussed in section 3, and tests of more general dynamics all accept this specification. As with the UK section above, we proceed in four stages. First, we estimate the specification of Case et al (2005), equation (2.1). All versions of this include intercepts, seasonals, and the dummies included in equation (5.5), but exclude any effects of credit market liberalization. The model shows a significant housing wealth effect, but a small and insignificant stock market wealth effect, see Table 5, column 1. There is a negative shift on the change of the log of housing wealth after 1986, possibly reflecting the decline in the ratio of housing wealth to income, see Figure 4. Taking this into account, after 1986, the elasticity of consumer spending with respect to real housing wealth is around 100 times as large as that of illiquid financial wealth. However, when the rate of growth in stock market wealth is averaged over two years, it is significant, see column 2. As in the UK, this gives quite a different impression of the relative role of financial and housing wealth. There is no long-run income effect, but repeating the estimation using personal disposable income including property income, gives a significant though very small long-run effect of income (0.08).

Second, we estimate a version of equation (5.5) assuming all coefficients are constant and excluding the direct and interaction effects of the credit market liberalization variable, CCI. The results are shown in column 1 of Table 6 . The fit is somewhat improved and the speed of adjustment rises to 0.21 , consistent with significant long-run income and wealth effects. The estimated marginal propensities to spend out of liquid assets minus debt, housing wealth and illiquid financial wealth are positive though not all individually significant. Perhaps to compensate, the self-employment income proxy based on broad property income, 1978 and in 1984. SOWETO is a dummy capturing the effects of school riots in early 1976. 
is highly significant but with an implausibly large coefficient. The real interest rate effect is positive but insignificant and omitted in the reported results. In terms of dynamic effects, the uncertainty effects are not significant and also omitted. The effect of forecast income growth is positive but not precisely estimated, while that of the change of income is positive and strongly significant. The housing capital gain last quarter, measured as the lagged housing wealth to income ratio scaled by the log change in real house prices last quarter is positive and significant. The debt-weighted nominal interest rate effect is negative but not quite significant. The sales tax dummies are important as in the UK.

Third, we allow $C C I$ to play an intercept role, though exclude its interaction effects. The results are shown in column 2 of Table 6. The dummy components of CCI are mostly significant, see Table 8, column 2, and their inclusion doubles the speed of adjustment. The real interest rate effect is now negative and significant. The long-run wealth effects are now all significant: the marginal propensity to spend out of net liquid wealth is estimated at 0.17 , out of directly held illiquid financial wealth at 0.05 and out of pension wealth at 0.09 and out of housing wealth at 0.14 , though the capital gain effect remains significant. Among the dynamic effects, forecast income growth has a strongly significant positive effect. The uncertainty proxies, the change in capacity utilization and nominal exchange rate volatility are correctly signed but still insignificant, but that of debt-weighted nominal interest rates has become strongly significant. However, the change in current income now appears less relevant.

Finally, we estimate the fully general version of equation (3.11), as shown in equation (5.5), allowing also for interaction effects with $C C I$. A general form of the composite uncertainty term is allowed to depend upon changes in capacity utilization as a proxy for changes in the unemployment rate, exchange rate volatility, inflation volatility and income volatility, and an interaction effect with $C C I$ reducing the weight on uncertainty as $C C I$ rises. These results, after eliminating most insignificant effects, are shown in column 3 of Table 8 .

The fit of the equation has much improved. The coefficients on the CCI dummies are mostly significant, some very strongly so, and the speed of adjustment has risen by almost 30 percent, suggesting around 45 percent of a full adjustment to shocks takes place in the current quarter. The wealth effects are all strongly significant, with the marginal propensity to spend out of net liquid wealth is estimated at 0.20 , out of directly held illiquid financial wealth at $0.08,0.05$ out of pension wealth and out of housing wealth at 0.10 , but rising to 0.15 at the peak of CCI. However, the shift effect with CCI is not precisely estimated. The real interest rate effect is significant and negative, though its shift with CCI is absent. Two income 
uncertainty proxies are relevant: changes in capacity utilization and exchange rate volatility. Their interaction with CCI is highly significant, suggesting a weaker role for uncertainty as credit becomes more easily available ${ }^{32}$. One further interaction effects stands out: the shift in the forecast income growth term with $C C I$ (forecast growth expectations now do not enter the equation on their own and neither do current income changes). The interaction of the negative debt weighted nominal interest rate effect with $\mathrm{CCI}$ is in the expected direction but is insignificant.

The relatively high value of the estimated marginal propensity to spend out of illiquid financial assets, especially directly held ones, is consistent with a downward bias in estimates of these asset values. As noted above, foreign assets, assets of unincorporated and unlisted companies are omitted from our estimates. It is possible that our estimates of housing wealth may also have a downward bias, though probably of a smaller extent. Our estimates do suggest that in South Africa, unlike the UK, the marginal propensity to spend for housing wealth or collateral is slightly larger than for illiquid financial assets, though the difference is not statistically significant. Given that since the early 1980 s to 2003 , real housing wealth fluctuates little around a trend, it is perhaps not surprising that the housing wealth effect and its shift with CCI is not very precisely estimated. The dramatic rises in housing wealth from 2003 to 2005 may well resolve this problem ${ }^{33}$. However, it is also possible that despite our efforts in modeling income growth expectations and uncertainty, asset prices in South Africa represent a mix of wealth effects and some confidence factor missing from the consumption model. In a country subject to such large political and institutional shocks, it is bound to be harder to separate these two influences.

\subsection{The Household Debt Equation}

In contrast to the vast literature on consumption, little systematic econometric work exists on household debt, see the review in F-C M. The canonical REPIH model of the representative consumer has little to contribute to understanding the determination of aggregate household debt. In this model there is only a single asset, so that it can explain only the evolution of aggregate net wealth. In practice, consumers have multiple motives for holding debt. These include consumption smoothing through temporary income downturns; or in anticipation of

${ }^{32}$ In fact, we have constrained the parameter on the interaction term, $\alpha_{2 \mathrm{c}} / \alpha_{2}$, to -3.5 (around one standard deviation below the freely estimated value of -4.5 ), which, given that CCI peaks at 0.27 , prevents perversely signed uncertainty effects. 
higher future income, financing the acquisition of consumer durables and housing, human capital investment through education or training, or portfolio investment in financial assets when returns prospects look favourable; and to offset what could otherwise be excessive amounts of saving implied by occupational pension rules.

Given asymmetric information between lenders and borrowers, assets have an important collateral role. Most debt is backed by collateral in the form of durables, housing and other assets. In a closed financial system, much of household saving in liquid asset form is recycled by the financial system into lending for other households, suggesting that at the aggregate level, current end-of-period household debt should increase with liquid and illiquid asset stocks at the end of the previous period. Variables such as income, interest rates and proxies for income uncertainty, reflecting economic conditions during the period, will also influence current debt. We use a log formulation, linking the log debt to income ratio with log ratios to income of the various assets, and to the log of real income.

Credit market liberalization could impact in several ways on this long-run relationship. A direct, positive effect on debt should result from the different facets of financial liberalization, with, for example, more freely available credit card loans, lower housing down-payments as a fraction of house values, and housing equity loans more freely available to existing owners. There may also be (indirect) interaction effects from financial liberalization. One expects an increased coefficient on housing wealth to income, given more liberal use as collateral. A reduced coefficient on liquid assets is likely, as bank lending then becomes less constrained by liquid deposit holdings of the personal sector. Indeed, at the micro-level, households holding significant levels of liquid assets have no need to take on debt, suggesting a negative relationship between current debt and lagged liquid assets. However, in the long-run, debt should move broadly in proportion to assets as a whole, even after financial liberalization. We constrain the shift in the liquid asset effect with CCI to be minus that of the shift in the housing wealth term, to preserve the long-run relationship between debt and assets.

Other possible interaction effects are with income uncertainty, expected to become less of a constraint on debt after financial liberalization; and with income growth expectations, which should become more significant, reflecting the desires of households to borrow. One expects a negative real and/or nominal interest rate effect, the latter representing cash constraints from higher debt service ratios. The easing of credit conditions should make

\footnotetext{
${ }^{33}$ However, updating the estimates to the end of 2005 reveals little change in the housing wealth effects for
} 
the real interest rate effect more powerful and the nominal interest rate effect less powerful, for reasons already discussed in the consumption context.

The evidence in F-C M suggests a positive effect on debt from the proportion of the adult population in younger age brackets e.g. 20-35 or 20-39. In the absence of reliable time series data on the age distribution of the South African population, we use the population growth rate as a proxy, since faster growth rates will be associated with a younger age structure.

This discussion is summarised in the following equation which has a similar structure, including partial adjustment form, to the consumption equation (terms defined in Table 2):

$$
\begin{aligned}
\Delta \log \operatorname{debt}_{t}= & \delta\left[\delta_{0}+\log \mathrm{y}_{\mathrm{t}-1}-\log \mathrm{debt}_{\mathrm{t}-1}+\delta_{0 c} C C I+\delta_{1} r m a 8_{t-1}+\left(\delta_{1 c} \times C C I\right) r m a 8_{t-1}\right. \\
& \left(\delta_{2}+\delta_{2 c} \times C C I\right) \theta_{t}+ \\
& \left(\delta_{3}+\delta_{3 c} \times C C I\right) E_{t} \Delta \log \text { yperm }_{t+12}+\delta_{4}\left(y^{\text {prop }} / y\right)_{t}+\delta_{5} \log y_{t} \\
& +\left(\phi_{1}-\phi_{2}-\phi_{3}-\phi_{4}\right) \log \left(\text { LA }_{t-1} / y_{t}\right)+\phi_{2} \log \left(\text { DIFAma }_{t-1} / y_{t}\right) \\
& +\phi_{3} \log \left(P A m a_{t-1} / y_{t}\right) \\
& \left.+\phi_{4} \log \left(H A_{t-1} / y_{t}\right)+\left(\phi_{4 c} \times C C I\right)\left(\log \left(H A_{t-1} / y_{t}\right)-\log \left(L A_{t-1} / y_{t}\right)\right)\right] \\
& +\left(\eta_{1}+\eta_{1 c} \times C C I\right) \Delta \log y_{t}+\left(\eta_{2}+\eta_{2 c} \times C C I\right) \Delta_{3} \log n r_{t} \\
& +\eta_{3} \Delta_{8} \log (\text { popma })+\text { dummies }+\varepsilon_{2 t}
\end{aligned}
$$

The main differences from the form of the consumption equation are three, the use of $\log$ asset/income ratios, the relaxation of long-run homogeneity with respect to income and assets and the population growth effect.

Table 7 provides estimates corresponding to columns 1-3 of the consumption estimates in Table 6. When CCI effects are missing, the worse fit, evidence of first order residual autocorrelation, and implausibly large income effects are symptoms of misspecification. When CCI is included, the estimates suggest a long-run shift effect of around 0.45 on log debt comparing pre 1981 with post 1996. The specifications including CCI tend to yield more significant real and nominal interest rate effects. Current and expected income growth effects are generally insignificant. The shift in the role of assets $\phi_{4 c}$ is not very well determined on these estimates. $^{34}$ The long-run elasticity of debt with respect to assets is

\footnotetext{
consumption.

${ }^{34}$ However, on data up to the end of 2005, after a house price boom, the estimate of $\phi_{4 c}$ becomes larger and significant, while other parameters are little changed.
} 
around 1.1 when interaction effects are included, while that with respect to income is around $1.5(1.6-1.1+1)$, similar to estimates in F-C M.

\section{Conclusions}

There is widespread disagreement about the role of housing wealth in explaining consumption. This paper has argued that much of the empirical literature is marred by poor controls for the common drivers both of house prices and consumption, including income, income growth expectations, interest rates, credit supply conditions, other assets and indicators of income uncertainty (such as changes in the unemployment rate). In particular, the easing of credit supply conditions is usually followed by a house price boom. Then the failure to control for the direct effect of credit liberalization on consumption can overestimate the effect of housing wealth or collateral on consumption. This paper has proposed an empirical model, grounded in theory, to measure wealth effects on consumption. The model has more complete controls than hitherto used in the literature, including shifts in credit conditions, and the forecast growth rate of income to proxy expectations.

The consumption model is estimated for the UK and South Africa. Both countries experienced substantial credit market liberalization and rising consumption to income ratios. However, South Africa's circumstances in the 1980s prevented an asset price boom, thus illuminating the direct role of credit liberalization.

One contribution of the paper is to control for variations in credit conditions so as better to measure housing wealth or collateral effects. Another contribution is to illuminate the multifaceted effects of credit market liberalization on consumption. Previous attempts to measure the effects of financial liberalization on consumption are unsatisfactory. Attempts to do so through Euler equations, modified as in Hall and Mishkin (1982) and Campbell and Mankiw (1989, 1991), suffer from four major limitations. Two of these are mainly theoretical, and the other two are empirical.

The theoretical limitations arise from two assumptions, that credit-constrained households simply spend their income; and that the effect of financial liberalization is confined to reducing the proportion or consumption share of credit-constrained households. The first of these has been shown to be inadequate by buffer-stock models of consumption due to Deaton (1991) and Carroll (1997, 2001a, 2001b). The second assumption fails to recognize that there are three distinct elements of liberalization in credit markets. The 
literature predominantly focuses on one of these: the easing of restrictions on credit for consumers wishing to smooth consumption over time in response to higher expected future income (e.g. through easier access to unsecured bank loans and credit-card facilities). At least as important, however, are the two which operate mainly through mortgage markets: the reduction in down-payments by first-time home buyers, discussed by Japelli and Pagano (1994); and the more generous attitudes to new borrowing secured by existing housing collateral.

The easing of credit in the mortgage market has the implication that consumption to income ratios will be raised as young consumers have to save for fewer years to accumulate the deposit required to access the housing ladder, while the 'spendability' of housing collateral of home-owners is increased.

Neglect of these theoretical effects reduces the usefulness of conventional modified Euler equations as empirical approximations. This is compounded by two empirical limitations. The first is endemic to the Euler equation approach: the neglect of long-run information, the importance of which is emphasized in the econometric literature on cointegration. The other empirical problem in the literature has been to identify proxies for financial liberalization. Of these, the debt to income ratio has perhaps proved the most popular, but it risks confounding income, income expectations, interest rates and asset holdings with financial liberalization.

This paper addresses each of these issues using data from the UK and South Africa. For the UK, the credit conditions index is taken from Fernandez-Corugedo and Muellbauer (2006). For South Africa, the credit conditions index is captured through a spline function common to jointly estimated consumption and household debt equations. The parameters incorporate qualitative information on the timing of key institutional changes in credit markets. In both countries a major part of the rise of the consumption to income ratio from pre-1980 to the end of the century is explained by the easing of credit availability, even when offsets such as the rise of real interest rates and their greater impact on consumption, and the reduced role of income uncertainty are taken into account, see Aron and Muellbauer (2000a) for a discussion of the general equilibrium versus partial equilibrium effects for South Africa.

The empirical models for the two countries have strikingly similar features, despite the very different macroeconomic histories. Credit market liberalization increases the average propensity to consume out of income in both countries and its inclusion brings clear benefits in finding better determined negative real interest rate effects on consumption. The interaction effects of credit market liberalization in increasing the roles of expected income 
growth and of the real interest rate, and reducing the role of changes in the nominal interest rate and in uncertainty are confirmed in both countries, though the interest rate interaction effects are weaker in South Africa. The higher marginal propensity to spend out of wealth in South Africa compared to the UK probably reflects an underestimate of wealth, though it may also signal a missing confidence factor, not controlled for by our income expectations and uncertainty measures. However, time variations in wealth appear to be relatively wellmeasured, judging by the stability and significance of the coefficients. It appears that in the UK, the marginal propensity to spend out of housing wealth in recent years has been similar to that out of illiquid financial wealth, while in South Africa, it has been slightly greater. In neither country does the evidence support the claim by Case et al (2005) that housing wealth or collateral effects greatly exceed stock market wealth effects, though our evidence is that the marginal propensities are a little higher for housing. However, different specifications for the income growth forecasting equations embodying lesser or greater asset price effects do influence the size of the wealth effects. The estimates we have reported are for growth forecasting equations where asset prices have a sizable role.

The consumption model estimates throw light on the monetary transmission mechanism in the UK and South Africa, showing that there are multiple channels for the effect of interest rates on consumption expenditure. This is highly relevant for policy making (e.g. see Aron and Muellbauer (2005) for a discussion of policy choices in South Africa following the 60 percent rise in house prices between 2003 and 2005). The model also explains the post-2000 breakdown in the bivariate correlation of consumption and real house prices in the UK, which has caused the Bank of England some puzzlement, and a notable breakdown in the new Bank of England Quarterly Model, see Benito et al (2006), p.151. However, our model implies that the responsiveness of the housing market to lower interest rates (see Cameron et al. 2006 for estimates), played an important part in sustaining consumption and therefore growth in the UK in this period.

A rise in short-term interest rates has negative direct effects on consumer spending, but there appear to be even larger indirect effects via asset prices and income expectations. Given the multiple possible influences on asset prices in small open economies - including foreign interest rates, terms of trade and foreign equity prices - to quantify the marginal effect of domestic interest rate changes alone requires separate models for the main asset prices of equities, bonds and housing, in addition to the consumption function and income forecasts. This remains an important task for future work. 


\section{References}

Aoki, K, Proudman, J. and G. Vlieghe. 2004. 'House prices, consumption and monetary policy: a financial accelerator approach.' Journal of Financial Intermediation 13(4): 414-435.

Aoki, K., Proudman, J. and G. Vlieghe. "Houses as Collateral: Has the Link between House Prices and Consumption in the U.K. Changed?" Federal Reserve Bank of New York Economic Policy Review.

Aron, J., J. Muellbauer and J. Prinsloo. 2006a. "Estimating the Balance Sheet of the Personal Sector in an Emerging Market Country, South Africa 1970-2003." chapter in Davies, J. and Shorrocks, T. (eds.), Personal Assets from a Global Perspective, Oxford University Press (forthcoming).

Aron, J., J. Muellbauer and J. Prinsloo. 2006b. "Estimating household-sector wealth in South Africa." Quarterly Bulletin, South African Reserve Bank, June, 61-72.

Aron, J and Muellbauer, J. 2006b. "Estimates of Household Sector Wealth for South Africa, 19702003." Review of Income and Wealth 52(2):285-308.

Aron, J and J. Muellbauer. 2005. "Monetary policy, macro-stability and growth: South Africa's recent experience and lessons." World Economics: 6(4): 123-147, December. (http://www.worldeconomics-journal.com/)

Aron, J and J. Muellbauer. 2002a. "Interest rate effects on output: evidence from a GDP forecasting model for South Africa." IMF Staff Papers 49 (November, IMF Annual Research Conference): 185-213. (also http://www.cepr.org/pubs/new-dps/dplist.asp?authorid=131312)

Aron, J. and J. Muellbauer. 2002b. "Estimating Monetary Policy Rules for South Africa", in Norman Loayza and Klaus Schmidt-Hebbel (eds) "Monetary Policy: Rules and Transmission Mechanisms", Series on Central Banking, Analysis and Economic Policies, Volume 4, Central Bank of Chile, pages 427-475. (http://www.bcentral.cl/books/v4/v4.htm)

Aron, J. and J. Muellbauer. 2000a. "Personal and Corporate Saving in South Africa", World Bank Economic Review 14 (3): 509-544. (also http://www.cepr.org/pubs/newdps/dplist.asp?authorid $=131312$ )

Aron, J. and J. Muellbauer, 2000b. "Financial Liberalization, Consumption and Debt in South Africa." WPS/2000.22, CSAE Working Paper Series, Oxford.

Attanasio, Orazio, Laura Blow, Robert Hamilton and Andrew Leicester. 2005. "Booms and Busts: Consumption, house prices and expectations", IFS working paper 05/24.

Bandiera, Oriana, Gerard Caprio, Patrick Honohan, and Fabio Schianterelli. 2000. "Does Financial Reform Raise or Reduce Private Savings?" Review of Economics and Statistics 82 (2): 239-263.

Banerjee, Anindya, Juan Dolado, John Galbraith and David F. Hendry. 1993. Co-Integration, Error Correction and the Econometric Analysis of Non-Stationary Data. Oxford: Oxford University Press.

Barrel, R. and E. P. Davis. 2004. "Consumption, Financial and Real Wealth in the G-5." NIESR, Discussion Paper Series, no 232.

Bayoumi, Tamim. 1993a. "Financial Deregulation and Consumption in the United Kingdom." Review of Economics and Statistics 75 (3): 536-39.

Bayoumi, Tamim. 1993b. "Financial Deregulation and Household Saving." Economic Journal 103 (421): 1432-43.

Benito, A., J. Thompson, M. Waldron, and R. Wood (2006), "House Prices and Consumer Spending", Bank of England Quarterly Bulletin, Summer, 142-154.

Boone, L. Girouard, N. and I. Wanner. 2001. "Financial Market Liberalization, Wealth and Consumption." OECD Economics Dept WP 308, September. 
Bostic, Raphael, Stuart Gabriel and Gary Painter. 2005. "Housing Wealth, Financial Wealth, and Consumption: New Evidence from Micro Data 1." June, symposium paper, NUS-HKU, Singapore.

Bover, O. 2005. "Wealth Effects on Consumption: Microeconometric Estimates from the Spanish Survey of Household Finances." Bank of Spain working paper, Documentos de Trabajo, No 0522.

Brodin, P. A. and Ragnar Nymoen, (1992), "Wealth Effects and Exogeneity: the Norwegian Consumption Function 1966(1)-1989(4)", Oxford Bulletin of Economics and Statistics 54 (3): 431-54.

Byrne, J. P. and P. E. Davis. 2003. "Disaggregate Wealth and Aggregate Consumption: an Investigation of Empirical Relationships for the G7." Oxford Bulletin of Economics and Statistics 65 (2), May: 197-220.

Cameron, G. and J. Muellbauer. 2000. "Earnings Biases in the United Kingdom Regional Accounts: Some Economic Policy and Research Implications." Economic Journal, 110, F412-29.

Campbell, J. Y. and N. Gregory Mankiw. 1991. "The Response of Consumption to Income: A CrossCountry Investigation." European Economic Review 35 (4): 723-56.

Campbell, J. Y. and Gregory Mankiw. 1989. "Consumption, Income and Interest Rates; Reinterpreting the Time Series Evidence." In O. J. Blanchard and Stanley Fischer, eds., NBER Macroeconomics Annual, 1989. Cambridge, Mass: MIT Press.

Campbell, John Y. and João F. Cocco. 2005. "How Do House Prices Affect Consumption? Evidence From Micro Data." NBER Working Paper No. 11534 (August), (forthcoming Journal of Monetary Economics).

Carroll, C. 2001a. 'Death to the Log-Linearized Consumption Euler Equation! (And Very Poor Health to the Second-Order Approximation),' Advances in Macroeconomics, Berkeley Electronic Press, vol. 1(1), pages 1003-1003.

Carroll, C.D. 2001b. "A Theory of the Consumption Function with and without Liquidity Constraints", Journal of Economic Perspectives, 15(3), 2001, 23-45.

Carroll, C. D. 1997. "Buffer-Stock Saving and the Life Cycle/Permanent Income Hypothesis." Quarterly Journal of Economics 112 (1): 1-55.

Case, Karl E., John M. Quigley and Robert J. Shiller. 2005. "Comparing Wealth Effects: The Stock Market versus the Housing Market." Advances in Macroeconomics. 5(1) Article 1. http://www.bepress.com/bejm/advances/vol5/iss1/art1.

Catte, P., N. Girouard, R. Price and C. André.,(2004. "Housing markets, wealth and the business cycle", OECD Economics Department Working Paper 394. check

Davidson, James, David F. Hendry, Frank Srba and Stephen Yeo. 1978. "Econometric Modelling of the Aggregate Time-Series Relationship Between Consumers' Expenditure and Income in the United Kingdom." Economic Journal 88 (352): 661-92.

De Kock, Gerhard. 1978. "Commission of Inquiry into the Monetary System and Monetary Policy in South Africa, Interim Report." Government Printer, Pretoria.

de Kock, Gerhard. 1985. "Commission of Inquiry into the Monetary System and Monetary Policy in South Africa, Final Report." Government Printer, Pretoria.

Deaton, Angus. 1991. "Saving and Liquidity Constraints", Econometrica 59 (5): 1221-1248.

Deaton, A. 1992. Understanding Consumption, Oxford: Clarendon Press.

Deaton, Angus. 1999. "Saving and Growth." In Klaus Schmidt-Hebbel and Luis Serven, eds., The Economics of Saving and Growth. Cambridge: Cambridge University Press.

Dickey, D. A. and Fuller, W. A. 1979. "Distribution of the Estimators for Autoregressive Time Series with a Unit Root." Journal of the American Statistical Association 74 (366): 427-31.

Dvornak N and M Kohler. 2003. "Housing wealth, stock market wealth and consumption: a panel analysis for Australia." Reserve Bank of Australia Research Discussion Paper, RDP2003-07.

Engelhardt, Gary. V. 1996. "Consumption, Down Payments and Liquidity Constraints", Journal of Money Credit and Banking, 28(2), 255-271. 
Engle, Robert F. and Clive W. J. Granger. 1987. "Cointegration and Error Correction: Representation, Estimation and Testing." Econometrica 55 (2): 251-76.

Fernandez-Corugedo, Emilio and John Muellbauer. 2006. "Consumer Credit Conditions in the U.K.." forthcoming, Bank of England working paper.

Friedman, M. 1957. A Theory of the Consumption Function. Princeton: Princeton University Press.

Friedman, M. 1963. "Windfalls, the 'Horizon' and Related Concepts in the Permanenet Income Hypothesis", in Carl Christ et al, eds., Measurement in Economics. Stanford University Press.

GEAR (1996), Growth, Employment and Redistribution: A Macro-Economic Strategy, Ministry of Finance, South Africa.

Hall, Robert E. 1978. "Stochastic Implications of the Life Cycle-permanent Income Hypothesis: Theory and Evidence." Journal of Political Economy 86 (6): 971-87.

Hall, Robert E. and Frederick S. Mishkin. 1982. "The Sensitivity of Consumption to Transitory Income: Estimates from Panel Data on Households." Econometrica 50 (2): 461-81.

Hayashi, F. 1985. "The Permanent Income Hypothesis: Estimation and Testing by Instrumental Variables.” Journal of Political Economy 90: 895-916.

Hendry, David F. and Thomas Von Ungern Sternberg. 1981. "Liquidity and Inflation Effects on Consumer's Expenditure." In Angus Deaton, ed., Essays in Theory and Measurement of Consumers' Behaviour. Cambridge: Cambridge University Press.

Honohan, Patrick. 1999. "Financial Policies and Saving." In Klaus Schmidt-Hebbel, and Luis Serven, eds., The Economics of Saving and Growth. Cambridge: Cambridge University Press.

Iacoviello, Matteo. 2004. "Consumption, House Prices and Collateral Constraints: a Structural Econometric Analysis." Journal of Housing Economics, 13(4): 305-321.

Iacoviello, Matteo. 2005. "House Prices, Borrowing Constraints and Monetary Policy in the Business Cycle.” American Economic Review 95: 739-64.

Jappelli, Tullio and Marco Pagano. 1994. "Saving, Growth and Liquidity Constraints." Quarterly Journal of Economics 109(1): 83-109.

Johansen, Soren and Katarina Juselius. 1990. "Maximum Likelihood Estimation and Inference on Cointegration - with Applications to the Demand for Money." Oxford Bulletin of Economics and Statistics 52 (2): 169-210.

Katz Commission. 1996. Third Interim Report of the Commission of Inquiry into Certain Aspects of the Tax Structure of South Africa, Government Printer, Pretoria.

Kennedy, N. and P. Andersen (1994), "Household Saving and Real House Prices: An International Perspective," Bank for International Settlements Working Paper, No. 21.

Lehnert,A. (2004). 'Housing, Consumption, and Credit Constraints'. Board of Governors of the Federal Reserve System, Finance and Economics Discussion paper 2004-63.

Lettau, Martin and Sydney C. Ludvigson. 2004. "Understanding Trend and Cycle in Asset Values: Reevaluating the Wealth Effect on Consumption." American Economic Review 94(1): 276-299.

Ludwig, Alexander and Torsten Sloek. 2002. "The Impact of Changes in the Stock Prices and House Prices on Consumption in OECD Countries," IMF Working Paper 02/1, International Monetary Fund.

Lucas, Robert E. 1976. "Econometric Policy Evaluation: a Critique." Carnegie-Rochester Conference Series Supplement to the Journal of Monetary Economics 1: 19-46.

Lustig, H. and S. Van Niewerburgh (2005) "Housing Collateral, Consumption Insurance and Risk Premia: an Empirical Perspective", Journal of Finance, 60(3) 1167-1219.

MacKinnon, J. G. 1991."Critical Values for Cointegration Tests.” In Robert Engle, and Clive Granger, eds., Long-run Economic Relationships: Readings in Cointegration. Oxford: Oxford University Press. 
Maclennan, Duncan, John Muellbauer and Mark Stephens (1998, 2000). “Asymmetries in Housing and Financial Market Institutions and EMU", (with Duncan Maclennan and Mark Stephens), Oxford Review of Economic Policy, 14, 1998, no 3, 54-80. Revised version in T. Jenkinson (ed), Readings in Macroeconomics, OUP, 2000.

Miles, D. (1992), "Housing Markets, Consumption and Financial Liberalization in the Major Economies," European Economic Review, pp. 1093-1136.

Miles, David 1994. Housing, Financial Markets, and the Wider Economy. New York: Wiley.

Mouton Report. 1992. "Report of the Committee of Investigation into a Retirement Provision System for South Africa." Government Printer, Pretoria.

Muellbauer, John. 1996. "Income Persistence and Macropolicy Feedbacks in the US", Oxford Bulletin of Economics and Statistics $58:$ 703-733.

Muellbauer, John. 1988. "Habits, Rationality and Myopia in the Life-Cycle Consumption Function." Annales d'Economie et de Statistique 9: 47-70.

Muellbauer, John and Anthony Murphy. 1993. "Income Expectations, Wealth and Demography in the Aggregate UK Consumption Function “, presented at HM Treasury Academic Panel 1993, see www.housingoutlook.co.uk.

Muellbauer, John and Ralph Lattimore. 1995. "The Consumption Function: A Theoretical and Empirical Overview." In Hashem Pesaran and Michael Wickens, eds., Handbook of Applied Econometrics. Oxford: Blackwell.

Muellbauer, John and Anthony Murphy. 1995. "Explaining Regional Consumption", presented at Bank of Portugal Conference on the Microeconomics of Saving, Lisbon 1995, ms Nuffield College, Oxford.

Otsuka, Misuzu (2006) Essays on household portfolio and current account dynamics ProQuest/UMI 2006.

Patterson, K. D. 1984. "Net Liquid Assets and Net Illiquid Assets in the UK Consumption Function: Some Evidence for the UK." Economic Letters 14(4): 389-95.

Prinsloo, J. W. 2000. "The Saving Behaviour of the South African Economy." Occasional Paper No. 15, Pretoria: South African Reserve Bank, November.

Poterba, J. M. and J. M. Manchester. 1989. "Second Mortgages and Household Saving." Regional Science and Urban Economics 19 (2): 325-46.

Rajan, R. G. 2005. "Has Financial Development Made the World Riskier?" http://www.kc.frb.org/PUBLICAT/SYMPOS/2005/sym05prg.htm

Sarno, Lucio and Mark Taylor. 1998. "Real Interest Rates, Liquidity Constraints and Financial Deregulation: Private Consumption Behaviour in the U.K." Journal of Macroeconomics 20 (2): 221-42.

Schmidt-Hebbel, Klaus, and Luis Serven. 1999. The Economics of Saving and Growth. Cambridge: Cambridge University Press.

Schmidt-Hebbel, Klaus, and Luis Serven. 1997. "Saving Across the World: Puzzles and Policies." World Bank Discussion Paper 354, World Bank, Washington, D.C..

Skinner, J. 1988. "Risky Income, Life-cycle Consumption, and Precautionary Saving." Journal of Monetary Economics 22: 237-55.

Zeldes, Stephen. 1989. "Optimal Consumption with Stochastic Income: Deviations from Certainty Equivalence.” Quarterly-Journal-of-Economics 104(2): 275-98.

Zellner, Arnold, D. S. Huang, and L. C. Chau. 1965. "Further Analysis of the Short-Run Consumption Function with Emphasis on the Role of Liquid Assets." Econometrica 33 (3): 571-81. 
Table 1: Selected survey of consumption and asset studies

\begin{tabular}{|c|c|c|c|c|c|c|c|c|c|c|c|}
\hline \multirow{3}{*}{ Study } & \multirow{3}{*}{$\begin{array}{l}\text { Homogeneity } \\
\text { issues }\end{array}$} & \multicolumn{10}{|c|}{ Controlling for the following variables: } \\
\hline & & \multirow{2}{*}{$\begin{array}{l}\text { Real } \\
\text { income }\end{array}$} & \multirow{2}{*}{$\begin{array}{l}\text { Income } \\
\text { growth } \\
\text { expectations }\end{array}$} & \multicolumn{2}{|c|}{ Credit conditions } & \multicolumn{4}{|c|}{ Wealth effects } & \multirow{2}{*}{$\begin{array}{l}\text { Interest } \\
\text { rates }\end{array}$} & \multirow[t]{2}{*}{ Uncertainty } \\
\hline & & & & $\begin{array}{l}\text { Direct } \\
\text { effect }\end{array}$ & Shift effect & $\log$ & $\Delta \log$ & level & disaggregation & & \\
\hline \multicolumn{12}{|l|}{ Micro-studies } \\
\hline $\begin{array}{l}\text { Bover }(2005) \\
\text { Spain } \\
2002\end{array}$ & $\begin{array}{l}\text { LR homog: NA } \\
\text { Country } \\
\text { heterog: NA }\end{array}$ & $\mathrm{NA}^{1}$ & $\mathrm{NA}^{1}$ & NA & NA & - & - & yes & $\begin{array}{l}\text { Financial assets and } \\
\text { housing assets }\end{array}$ & NA & NA \\
\hline $\begin{array}{l}\text { Bostic et al } \\
(2005) \\
\text { US pooled } \\
\text { cross-section } \\
1989-2001\end{array}$ & $\begin{array}{l}\text { LR homog: no } \\
\text { Country } \\
\text { heterog: NA }\end{array}$ & yes & No & no & no & yes & - & - & $\begin{array}{l}\text { Financial assets and } \\
\text { housing assets }\end{array}$ & no & no \\
\hline $\begin{array}{l}\text { Campbell \& } \\
\text { Cocco (2005) } \\
\text { UK FES 1988- } \\
2000\end{array}$ & $\begin{array}{l}\text { LR homog: NA } \\
\text { Country } \\
\text { heterog: NA }\end{array}$ & yes & No & $\mathrm{no}^{2}$ & $\mathrm{no}^{2}$ & yes & - & - & Housing assets and debt & yes & $\begin{array}{l}\text { yes, } \\
\text { unemployment }\end{array}$ \\
\hline $\begin{array}{l}\text { Attanasio et al } \\
(2005) \\
\text { UK FES 1978- } \\
2001\end{array}$ & $\begin{array}{l}\text { LR homog: NA } \\
\text { Country } \\
\text { heterog: NA }\end{array}$ & no & No & no & no & yes & - & - & Housing assets & no & No \\
\hline \begin{tabular}{l}
\multicolumn{2}{l}{ Lehnert(2004) } \\
US PSID \\
panel, 1968-99
\end{tabular} & NA & NA & NA & no & no & no & yes & No & no & no & No \\
\hline \multicolumn{12}{|l|}{ Macro-studies } \\
\hline $\begin{array}{lrr}\text { Case } & \text { et } & \text { al } \\
(2005) & \\
\text { Panel } & \text { US } \\
\text { states; panel } \\
14 & \text { OECD } \\
\text { countries } & \end{array}$ & $\begin{array}{l}\text { LR homog: yes } \\
\text { Country } \\
\text { heterog: no }\end{array}$ & yes & No & no & $\begin{array}{l}\text { yes, } \\
1986 \\
\text { dummy } \\
\text { interacted } \\
\text { with } \Delta \log \\
\text { house }\end{array}$ & - & yes & - & $\begin{array}{l}\text { Differenced r stock } \\
\text { market wealth and } \\
\text { owner-occupied housing } \\
\text { wealth (eop) }\end{array}$ & no & No \\
\hline
\end{tabular}




\begin{tabular}{|c|c|c|c|c|c|c|c|c|c|c|c|}
\hline \multirow{3}{*}{ Study } & \multirow{3}{*}{$\begin{array}{l}\text { Homogeneity } \\
\text { issues }\end{array}$} & \multicolumn{10}{|c|}{ Controlling for the following variables: } \\
\hline & & \multirow{2}{*}{$\begin{array}{l}\text { Real } \\
\text { income }\end{array}$} & \multirow{2}{*}{$\begin{array}{l}\text { Income } \\
\text { growth } \\
\text { expectations }\end{array}$} & \multicolumn{2}{|c|}{ Credit conditions } & \multicolumn{4}{|c|}{ Wealth effects } & \multirow{2}{*}{$\begin{array}{l}\text { Interest } \\
\text { rates }\end{array}$} & \multirow[t]{2}{*}{ Uncertainty } \\
\hline & & & & $\begin{array}{l}\text { Direct } \\
\text { effect }\end{array}$ & Shift effect & $\log$ & $\Delta \log$ & level & disaggregation & & \\
\hline $\begin{array}{l}\text { Catte et al } \\
(2004) \\
\text { OECD } \\
\text { country panel }\end{array}$ & $\begin{array}{l}\text { LR homog: yes } \\
\text { Country } \\
\text { heterog: no }\end{array}$ & Yes & No & no & no & - & - & yes & $\begin{array}{l}\text { Financial assets and } \\
\text { housing assets }\end{array}$ & yes & $\begin{array}{l}\text { yes, } \\
\text { unemployment }\end{array}$ \\
\hline $\begin{array}{l}\text { Barrel \& } \\
\text { Davis (2004) } \\
\text { G5 country } \\
\text { panel, }\end{array}$ & $\begin{array}{l}\text { LR homog: for } \\
\text { some variants } \\
\text { Country } \\
\text { heterog: yes }\end{array}$ & Yes & No & no & no & yes & yes & - & Total net wealth & $\begin{array}{l}\text { level real } \\
\text { interest rate }\end{array}$ & No \\
\hline $\begin{array}{l}\text { Dvornak \& } \\
\text { Kohler (2003) } \\
\text { Panel states } \\
\text { Australian } \\
\text { 1984-01 }\end{array}$ & $\begin{array}{l}\text { LR homog: } \\
\text { problematic } \\
\text { Country } \\
\text { heterog: NA }\end{array}$ & Yes & No & no & no & - & - & yes & $\begin{array}{l}\text { Net housing wealth, } \\
\text { stock market wealth and } \\
\text { other wealth }\end{array}$ & No & No \\
\hline $\begin{array}{l}\text { Byrne \& } \\
\text { Davis (2003) } \\
\text { G7 country } \\
\text { panel }\end{array}$ & $\begin{array}{l}\text { LR homog: yes } \\
\text { Country } \\
\text { heterog: yes }\end{array}$ & Yes & No & no & no & yes & yes & No & $\begin{array}{l}\text { Illiquid assets (including } \\
\text { housing wealth), and } \\
\text { liquid assets }\end{array}$ & No & No \\
\hline $\begin{array}{l}\text { Ludwig } \& \\
\text { Sloek (2002) } \\
16 \quad \text { OECD } \\
\text { countries } \\
1960,1975-99 \\
\end{array}$ & $\begin{array}{l}\text { LR homog: no } \\
\text { Country } \\
\text { heterog: yes, } \\
\text { for } 2 \text { groups of } \\
\text { countries }\end{array}$ & Yes & No & $\begin{array}{l}1985 \\
\text { split }\end{array}$ & $\begin{array}{l}1985 \\
\text { split }\end{array}$ & yes & yes & No & $\begin{array}{l}\text { Stock and house price } \\
\text { indices }\end{array}$ & No & No \\
\hline $\begin{array}{l}\text { Boone et al } \\
(2001) \\
\text { G7 country } \\
\text { panel excl. } \\
\text { Germany } \\
\end{array}$ & $\begin{array}{l}\text { LR homog: yes } \\
\text { Country } \\
\text { heterog: yes }\end{array}$ & Yes & No & no & $\begin{array}{l}\text { yes, } \\
\text { interact } \\
\text { with } \\
\text { liberalised } \\
\text { dummy } \\
\end{array}$ & - & - & yes & $\begin{array}{l}\text { Financial assets and } \\
\text { housing assets }\end{array}$ & yes & $\begin{array}{l}\text { yes, } \\
\text { unemployment }\end{array}$ \\
\hline $\begin{array}{l}\text { Brodin } \quad \& \\
\text { Nymoen } \\
(1992)\end{array}$ & $\begin{array}{l}\text { LR homog: yes } \\
\text { Country } \\
\text { heterog: NA }\end{array}$ & yes & no & no & no & yes & - & - & $\begin{array}{l}\text { Aggregates all wealth, } \\
\text { including housing wealth }\end{array}$ & No & no \\
\hline
\end{tabular}




\begin{tabular}{|c|c|c|c|c|c|c|c|c|c|c|c|}
\hline \multirow{3}{*}{ Study } & \multirow{3}{*}{$\begin{array}{l}\text { Homogeneity } \\
\text { issues }\end{array}$} & \multicolumn{10}{|c|}{ Controlling for the following variables: } \\
\hline & & \multirow{2}{*}{$\begin{array}{l}\text { Real } \\
\text { income }\end{array}$} & \multirow{2}{*}{$\begin{array}{l}\text { Income } \\
\text { growth } \\
\text { expectations }\end{array}$} & \multicolumn{2}{|c|}{ Credit conditions } & \multicolumn{4}{|c|}{ Wealth effects } & \multirow{2}{*}{$\begin{array}{l}\text { Interest } \\
\text { rates }\end{array}$} & \multirow[t]{2}{*}{ Uncertainty } \\
\hline & & & & $\begin{array}{l}\text { Direct } \\
\text { effect }\end{array}$ & Shift effect & $\log$ & $\Delta \log$ & level & disaggregation & & \\
\hline \multicolumn{12}{|l|}{ Norway } \\
\hline $\begin{array}{l}\text { Kennedy \& } \\
\text { Andersen } \\
(1994) \\
15 \quad \text { OECD } \\
\text { countries } \\
1970-1992 \\
\end{array}$ & $\begin{array}{l}\text { LR homog: yes } \\
\text { Country } \\
\text { heterog: yes }\end{array}$ & Yes & no & no & No & - & - & yes & $\begin{array}{l}\text { Financial assets and } \\
\text { housing assets }\end{array}$ & yes & $\begin{array}{l}\text { yes, } \\
\text { unemployment }\end{array}$ \\
\hline $\begin{array}{l}\text { Muellbauer \& } \\
\text { Murphy } \\
(1995) \\
\text { UK regional } \\
\text { panel (11 } \\
\text { regions) } \\
1972-91\end{array}$ & $\begin{array}{l}\text { LR homog: yes } \\
\text { Regional } \\
\text { heterog: NA }\end{array}$ & Yes & yes & no & $\begin{array}{l}\text { yes, } \\
\text { indicator } \\
\text { derived } \\
\text { from data } \\
\text { on loan-to- } \\
\text { value } \\
\text { ratios for } \\
\text { mortgages } \\
\text { to first- } \\
\text { time } \\
\text { buyers }\end{array}$ & - & - & yes & $\begin{array}{l}\text { Liquid and illiquid assets } \\
\text { (measured at the end of } \\
\text { the previous year). } \\
\text { Separate allowance is } \\
\text { made for a real house } \\
\text { price effect }\end{array}$ & yes & $\begin{array}{l}\text { yes, } \\
\text { unemployment }\end{array}$ \\
\hline
\end{tabular}

Notes:

1. Proxied by a rich set of household characteristics e.g. education etc..

2. Less relevant for 1988-2000, since the main credit supply shift occurred pre-1988. 
Table 2: Variable Definitions for the UK and South Africa

\begin{tabular}{|c|c|}
\hline Variable & Definition of Variable \\
\hline \multicolumn{2}{|c|}{ UK Consumption Equation $\quad(1967 Q 1$ to 2005Q4) } \\
\hline$\Delta \log \mathrm{c}$ & Log real personal consumption (seas. adj.) \\
\hline $\mathrm{CCI}$ & Credit conditions index \\
\hline $\log \mathrm{y}-\log \mathrm{c}_{-1}$ & $\begin{array}{l}\text { Log non-property income - log lagged consumption, key element for the } \\
\text { long-run solution }\end{array}$ \\
\hline Real rate & Real tax adj. mortgage interest rate/100 (4 quart. MA) \\
\hline Real rate $\mathrm{x}$ CCI & The above interacted with the credit conditions index \\
\hline Uncertainty, $\theta$ & Annual change in the unemployment rate \\
\hline Uncertainty x CCI interaction & The above interacted with the credit conditions index \\
\hline $\begin{array}{l}\text { Uncertainty indicator from F-C M } \\
\text { x CCI interaction }\end{array}$ & F-C M index of uncertainty interacted with the credit conditions index \\
\hline E $\Delta \log$ yperm +12 & Log permanent minus log current non-property income, see equ. 3.5 . \\
\hline E $\Delta \log$ yperm $_{+12}$ x CCI & The above interacted with the credit conditions index \\
\hline Net liquid assets ${ }_{-1}$ income & $\begin{array}{l}\text { Ratio of (liquid assets (eopp) - debt (eopp)) to annualised current } \\
\text { income }\end{array}$ \\
\hline Illiquid financial assets $_{-1} /$ income $^{a}$ & $\begin{array}{l}\text { Ratio of directly-held securities (eopp) plus the pension assets (eopp, } 4 \\
\text { quart. MA) to annualised current income }\end{array}$ \\
\hline Housing wealth ${ }_{-1}$ income & Ratio of housing wealth (eopp) to annualised current income \\
\hline (Housing wealth-1 income $) \times \mathrm{CCI}$ & The above interacted with the credit conditions index \\
\hline$\Delta \log \mathrm{y}$ & Real income growth (seas. Adj.) \\
\hline$\Delta \log \mathrm{y} \times \mathrm{CCI}$ & The above interacted with the credit conditions index \\
\hline $\begin{array}{l}\text { Debt }{ }_{-1} / \text { income weighted change in log }_{\text {nominal interest rate }}\end{array}$ & $\begin{array}{l}\text { Ratio of mortgage debt lagged one period to income multiplied by the } 4- \\
\text { quarter change in log nominal tax adj. mortgage interest rate }+ \text { ratio of } \\
\text { unsecured debt lagged one period to income multiplied by the } 4 \text {-quarter } \\
\text { change in log nominal bank base interest rate }\end{array}$ \\
\hline $\begin{array}{l}\text { Debt/income weighted change in log nominal } \\
\text { interest rate x CCI }\end{array}$ & The above interacted with the credit conditions index \\
\hline Dummies & $\begin{array}{l}\text { +/- dummy for } 1979 \mathrm{q} 2 \text { and } 1979 \mathrm{q} 3 \text { for VAT advancement effect; } \\
\text { similar dummies for advancement effects in } 1968 \mathrm{q} 1 \text { and } 1973 \mathrm{q} 1 \text {. }\end{array}$ \\
\hline Change in incidence of long duration strikes & Change in working days lost due to strikes lagged 3 quarters \\
\hline SA Debt Equation $\quad(1971 q 1-2003 q 4)$ & \\
\hline$\Delta \log$ debt & Log change of debt (eocp) \\
\hline Log $(\text { debt/income })_{-1}$ & Log (household debt/nppdi) lagged 1 quarter \\
\hline$\overline{\mathrm{CCI}}$ & Credit conditions index \\
\hline $\log \mathrm{y}$ & Log of real income (nppdi) per capita (seas. adj.) \\
\hline $\log$ housing wealth $-1 / \mathrm{y}$ & Log ratio of housing wealth (eopp) to annualised current income \\
\hline CCI $x \log$ housing wealth $-1 / y$ & The above interacted with the credit conditions index \\
\hline $\log$ liquid assets $_{-1} / \mathrm{y}$ & $\begin{array}{l}\text { Log ratio of liquid assets (eopp, } 4 \text { quart.MA) to annualised current } \\
\text { income }\end{array}$ \\
\hline $\log$ directly held illiquid assetsma $1 / \mathrm{y}$ & $\begin{array}{l}\text { Log ratio of directly held illiquid assets (eopp, } 4 \text { quart.MA) to } \\
\text { annualised current income }\end{array}$ \\
\hline $\log$ pension wealthma $-1 / \mathrm{y}$ & $\begin{array}{l}\text { Log ratio of pension assets (eopp, } 4 \text { quart. MA) to annualised current } \\
\text { income }\end{array}$ \\
\hline real rate $(\mathrm{ma} 8)_{-1}$ & Real prime rate/100 (4 quart. MA), lagged one quarter \\
\hline CCI x real rate $(\mathrm{ma} 8)_{-1}$ & The above interacted with the credit conditions index \\
\hline$\left(y^{\text {prop }} / y\right)_{-1}$ & Ratio of property income to non-property income \\
\hline E $\Delta \log$ yperm +12 & Log permanent minus log current non-property income, see equ. 3.5 . \\
\hline Uncertainty, $\theta$ & $\begin{array}{l}\text { A linear combination of the two quarter change in the log of capacity } \\
\text { utilization and a one quarter lag on the four quarter moving average of } \\
\text { exchange rate volatility }\end{array}$ \\
\hline CCI $x$ uncertainty & Interaction of CCI and uncertainty \\
\hline$\Delta_{4} \log$ nominal interest rate & Annual log-change of prime interest rate \\
\hline
\end{tabular}




\begin{tabular}{|c|c|}
\hline Variable & Definition of Variable \\
\hline CCI x $\Delta_{4} \log$ nominal interest rate & Interaction of CCI with annual log-change of prime interest rate \\
\hline$\Delta_{8} \log$ population (ma4) & $\begin{array}{l}\text { Two year log change in population (defined as a four quarter moving } \\
\text { average) }\end{array}$ \\
\hline \multicolumn{2}{|l|}{ SA Consumption Equation $\quad(1971 q 1-2003 q 4)$} \\
\hline$\Delta \log \mathrm{c}$ & Growth rate of real personal consumption (seas. adj.) \\
\hline $\mathrm{CCI}$ & Credit conditions index \\
\hline $\log \mathrm{y}-\log \mathrm{c}_{-1}$ & $\begin{array}{l}\text { Log non-property income - log lagged consumption, key element for the } \\
\text { long-run solution }\end{array}$ \\
\hline Real rate (ma4) & Real prime rate/100 (4 quart. MA) \\
\hline Real rate $(\mathrm{ma} 4) \times \mathrm{CCI}$ & The above interacted with the credit conditions index \\
\hline Uncertainty, $\theta$ & $\begin{array}{l}\text { A linear combination of the two quarter change in the log of capacity } \\
\text { utilization and a one quarter lag on the four quarter moving average of } \\
\text { exchange rate volatility }\end{array}$ \\
\hline Uncertainty x CCI interaction & The above interacted with the credit conditions index \\
\hline $\mathrm{E} \Delta \log$ yperm +12 & Log permanent minus log current non-property income, see equ. 3.5 . \\
\hline $\mathrm{E} \Delta \log$ yperm $_{+12}$ x CCI & The above interacted with the credit conditions index \\
\hline$\left(y^{\text {prop }} / y\right)$ & Ratio of property income to non-property income \\
\hline Net liquid assets $_{-1} /$ income $^{2}$ & $\begin{array}{l}\text { Ratio of (liquid assets (eopp) - debt (eopp)) to annualised current } \\
\text { income }\end{array}$ \\
\hline Directly held illiquid financial assets $_{-1} /$ income $\left.\right|_{\text {ii }} ^{\mathrm{R}}$ & $\begin{array}{l}\text { Ratio of directly-held securities (eopp, 4-quart ma) to annualized current } \\
\text { income }\end{array}$ \\
\hline Pension assets $_{-1} /$ income & Ratio of pension assets (eopp, 4 quart. ma) to annualised current income \\
\hline Housing wealth ${ }_{-1}$ /income & Ratio of housing wealth (eopp) to annualised current income \\
\hline Housing wealth -1 income x CCI & The above interacted with the credit conditions index \\
\hline$\Delta \log \mathrm{y}$ & Real income (nnpdi) growth (seas. Adj.) \\
\hline$\Delta \log \mathrm{y} \times \mathrm{CCI}$ & The above interacted with the credit conditions index \\
\hline \begin{tabular}{|lll}
$\begin{array}{l}\text { Debt }_{1} / \text { income }_{\text {neighted }} \text { change in } \log R \\
\text { nominal interest rate }\end{array}$ & \\
\end{tabular} & $\begin{array}{l}\text { Ratio of debt lagged one period to income multiplied by the change in } \\
\text { log nominal prime interest rate }\end{array}$ \\
\hline $\begin{array}{l}\text { Debt }_{-1} / \text { income weighted change in } \log \mid \mathrm{T} \\
\text { nominal interest rate } \mathrm{x} \text { CCI }\end{array}$ & The above interacted with the credit conditions index \\
\hline Housing wealth gain & $\begin{array}{l}\text { Lagged housing wealth to income multiplied by the rate of change in the } \\
\text { real house price index, lagged one period }\end{array}$ \\
\hline Housing wealth gain $\mathrm{x}$ CCI & The above interacted with the credit conditions index \\
\hline Dummies & $\begin{array}{l}\text { Q1DU75 is a pre-1976 seasonal to reflect mis-measured seasonal } \\
\text { correction in the data before that date while Q4 is a seasonal. GST78 } \\
\text { and GST84 are temporary dummies taking values }+1,-1 \text { in successive } \\
\text { quarters, reflecting shifting of expenditure in anticipation of increases in } \\
\text { sales tax in } 1978 \text { and in } 1984 \text {. SOWETO is a dummy capturing the } \\
\text { effects of school riots in early } 1976 \text {. }\end{array}$ \\
\hline
\end{tabular}

1. eopp is "end of previous period", eocp is "end of current period", ma is "moving average", nppdi is "non-property personal disposable income"

2. Constructed asset data are not seasonally-adjusted 
Table 3: Case-Quigley-Shiller Specification of the UK Consumption Function 1967:1 to 2005:4

\begin{tabular}{|c|c|c|c|c|c|c|c|c|}
\hline Dependent variable & \multicolumn{4}{|c|}{ With non-property income } & \multicolumn{4}{|c|}{ With personal disposable income } \\
\hline Regressors & coefficient & t- ratio & coefficient & $t$-ratio & coefficient & $t$-ratio & coefficient & t- ratio \\
\hline$\Delta \log \mathrm{c}(-1)$ & $-4.2 \mathrm{E}-03$ & -0.073 & -0.013 & -0.23 & 0.016 & 0.26 & 0.011 & 0.18 \\
\hline$\Delta \log \mathrm{y}$ & 0.23 & 5.0 & 0.23 & 5.0 & 0.16 & 3.7 & 0.16 & 3.7 \\
\hline $\log y(-1)-\log c(-1)$ & 0.013 & 0.73 & 0.013 & 0.75 & 0.062 & 2.2 & 0.060 & 2.1 \\
\hline$\Delta \log$ house & 0.10 & 3.6 & 0.090 & 3.1 & 0.12 & 4.4 & 0.12 & 4.1 \\
\hline Dum $86 * \Delta \log$ house & 0.027 & 0.72 & 0.029 & 0.77 & 0.028 & 0.76 & 0.026 & 0.70 \\
\hline$\Delta \log$ stock & 0.012 & 1.4 & - & - & $9.70 \mathrm{E}-03$ & 1.1 & - & - \\
\hline$\Delta \log$ stock-1 & $4.0 \mathrm{E}-03$ & 0.47 & - & - & $5.3 \mathrm{E}-03$ & 0.60 & - & - \\
\hline$\Delta_{8} \log$ stockma 8 & - & - & 0.034 & 1.5 & - & - & 0.020 & 0.86 \\
\hline \multicolumn{9}{|c|}{ Diagnostics } \\
\hline s.e & \multicolumn{2}{|c|}{$7.11 \mathrm{E}-03$} & \multicolumn{2}{|c|}{$7.10 \mathrm{E}-03$} & \multicolumn{2}{|c|}{$7.33 \mathrm{E}-03$} & \multicolumn{2}{|c|}{ 7.34E-03 } \\
\hline Adj. $R^{2}$ & \multicolumn{2}{|c|}{0.611} & \multicolumn{2}{|c|}{0.613} & \multicolumn{2}{|c|}{$5.87 \mathrm{E}-01$} & \multicolumn{2}{|c|}{0.586} \\
\hline DW & \multicolumn{2}{|c|}{2.01} & \multicolumn{2}{|c|}{2.01} & \multicolumn{2}{|c|}{2.02} & \multicolumn{2}{|c|}{2.02} \\
\hline LM1 ( $p$ value) & \multicolumn{2}{|c|}{0.883} & \multicolumn{2}{|c|}{0.871} & \multicolumn{2}{|c|}{0.854} & \multicolumn{2}{|c|}{0.87} \\
\hline LM4 ( $p$ value) & \multicolumn{2}{|c|}{0.365} & \multicolumn{2}{|c|}{0.884} & \multicolumn{2}{|c|}{0.235} & \multicolumn{2}{|c|}{0.433} \\
\hline LMhet ( $p$ value) & \multicolumn{2}{|c|}{0.662} & \multicolumn{2}{|c|}{0.596} & \multicolumn{2}{|c|}{0.583} & \multicolumn{2}{|c|}{0.56} \\
\hline
\end{tabular}


Table 4: Estimates of the UK Consumption Function 1967:1 to 2005:4

\begin{tabular}{|c|c|c|c|c|c|c|c|}
\hline \multirow{2}{*}{\multicolumn{2}{|c|}{$\begin{array}{r}\text { Dependent variable } \\
\Delta \log \mathrm{c} \\
\text { Regressors }\end{array}$}} & \multicolumn{2}{|l|}{ No CCI terms } & \multicolumn{2}{|c|}{$\begin{array}{l}\text { CCI intercept effect; no } \\
\text { interaction effects }\end{array}$} & \multicolumn{2}{|c|}{$\begin{array}{l}\text { CCI intercept and } \\
\text { interaction effects } \\
\text { (parsimonious) }\end{array}$} \\
\hline & & \multirow{2}{*}{$\begin{array}{c}\text { coefficient } \\
0.27 \\
\end{array}$} & \multirow{2}{*}{$\begin{array}{c}\text { t- ratio } \\
7.3 \\
\end{array}$} & \multirow{2}{*}{$\begin{array}{c}\text { coefficient } \\
0.29 \\
\end{array}$} & \multirow{2}{*}{$\begin{array}{c}\text { - ratio } \\
8.2 \\
\end{array}$} & \multirow{2}{*}{$\begin{array}{c}\text { coefficient } \\
0.33 \\
\end{array}$} & \multirow{2}{*}{$\begin{array}{c}\text { - ratio } \\
10.7 \\
\end{array}$} \\
\hline $\begin{array}{l}\text { Speed of adjustment } \\
\text { (coefficient on } \log y-\log c_{-1} \text { ) }\end{array}$ & $\alpha$ & & & & & & \\
\hline Intercept & $\alpha_{0}$ & -0.11 & -3.5 & -0.14 & -4.5 & -0.033 & -2.1 \\
\hline CCI & $\alpha_{0 c}$ & & & 0.17 & 2.8 & 0.22 & 4.1 \\
\hline Real rate & $\alpha_{1}$ & -0.018 & -0.3 & -0.18 & -2.2 & -0.094 & -1.4 \\
\hline Uncertainty ( $\left.\Delta_{4} \mathrm{ur}\right), \theta$ & $\alpha_{2}$ & -0.018 & -5.7 & -0.018 & -6.3 & -0.018 & -7.3 \\
\hline $\mathrm{E} \Delta \log$ yperm +12 & $\alpha_{3}$ & 0.45 & 4.4 & 0.38 & 4.0 & 0.19 & 1.8 \\
\hline $\mathrm{E} \Delta \log$ yperm $_{+12}$ x CCI & $\alpha_{3 c}$ & & & & & 1.5 & 1.8 \\
\hline Net liquid assets/income & $\gamma_{1}$ & 0.15 & 5.0 & 0.19 & 5.5 & 0.13 & 6.9 \\
\hline $\begin{array}{l}\text { Illiquid financial } \\
\text { assets/income }{ }^{a}\end{array}$ & $\gamma_{2}$ & 0.033 & 5.9 & 0.031 & 6.2 & 0.024 & 7.4 \\
\hline Housing wealth/income & $\gamma_{3}$ & 0.041 & 4.8 & 0.037 & 4.9 & & \\
\hline Housing wealth/income x CCI & $\gamma_{3 c}$ & & & & & 0.13 & 8.9 \\
\hline $\begin{array}{l}\text { Debt/income weighted change } \\
\text { in log nominal interest rate }\end{array}$ & $\beta_{2}$ & -0.022 & -5.4 & -0.020 & -4.8 & -0.052 & -4.2 \\
\hline $\begin{array}{l}\text { Debt/income weighted change } \\
\text { in log nominal interest rate x } \\
\text { CCI }\end{array}$ & $\beta_{2 c}$ & & & & & 0.16 & 2.9 \\
\hline Strikes & $\beta_{3}$ & $-2.4 \mathrm{E}-03$ & -2.5 & $-2.3 \mathrm{E}-03$ & -2.5 & $-2.2 \mathrm{E}-03$ & -2.6 \\
\hline Change in credit controls & $\beta_{10}$ & $-1.3 \mathrm{E}-03$ & -4.0 & $-1.1 \mathrm{E}-03$ & -3.5 & $-8.6 \mathrm{E}-04$ & -4.2 \\
\hline \multicolumn{8}{|c|}{ Diagnostics } \\
\hline \multicolumn{2}{|l|}{ s.e } & \multicolumn{2}{|c|}{$6.3 \mathrm{E}-03$} & \multicolumn{2}{|c|}{$6.2 \mathrm{E}-03$} & \multicolumn{2}{|c|}{$5.8 \mathrm{E}-03$} \\
\hline \multicolumn{2}{|l|}{ Adj. $\mathrm{R}^{2}$} & \multicolumn{2}{|c|}{0.696} & \multicolumn{2}{|c|}{0.708} & \multicolumn{2}{|c|}{0.742} \\
\hline \multicolumn{2}{|l|}{ DW } & \multicolumn{2}{|c|}{1.82} & \multicolumn{2}{|c|}{1.83} & \multicolumn{2}{|c|}{2.00} \\
\hline \multicolumn{2}{|l|}{ LM1 ( $p$ value) } & \multicolumn{2}{|c|}{0.73} & \multicolumn{2}{|c|}{0.54} & \multicolumn{2}{|c|}{0.27} \\
\hline \multicolumn{2}{|l|}{ LM4 ( $p$ value) } & \multicolumn{2}{|c|}{0.08} & \multicolumn{2}{|c|}{0.04} & \multicolumn{2}{|c|}{0.03} \\
\hline \multicolumn{2}{|c|}{ LMhet ( $p$ value) } & \multicolumn{2}{|c|}{0.86} & & & 0. & \\
\hline
\end{tabular}

Notes: a. Coefficients correspond with equation (4.1) which is based on the theory equation (3.11).

b. All interaction terms are in the form of $(\mathrm{z}-$ mean $(\mathrm{z})) \mathrm{x}$ CCI, where the mean is computed over the $1980 \mathrm{Q} 4$ to 2001Q4 period in which CCI exceeds zero. 
Table 5: Case-Quigley-Shiller specification of the SA Consumption Function

\begin{tabular}{|c|c|c|c|c|c|c|c|c|}
\hline Dependent variable & \multicolumn{4}{|c|}{ With non-property income } & \multicolumn{4}{|c|}{ With personal disposable income } \\
\hline Regressors & coefficient & $t$-ratio & coefficient & t-ratio & coefficient & t-ratio & coefficient & t-ratio \\
\hline$\Delta \log \mathrm{c}(-1)$ & 0.01 & 0.1 & -0.04 & -0.6 & -0.01 & -0.2 & -0.06 & 1.0 \\
\hline$\Delta \log \mathrm{y}$ & 0.22 & 3.9 & 0.18 & 3.2 & 0.16 & 5.7 & 0.13 & 4.5 \\
\hline $\log y(-1)-\log c(-1)$ & 0.013 & 1.1 & 0.01 & 0.9 & 0.08 & 4.0 & 0.07 & 3.3 \\
\hline$\Delta \log$ house & 0.18 & 3.6 & 0.17 & 3.4 & 0.28 & 6.1 & 0.25 & 5.3 \\
\hline Dum $86 * \Delta \log$ house & -0.09 & 1.1 & -0.06 & 0.8 & -0.15 & 2.2 & -0.12 & 1.6 \\
\hline$\Delta \log$ stock & -0.00 & 0.0 & - & & 0.01 & 1.0 & - & \\
\hline$\Delta \log$ stock-1 & 0.001 & 0.1 & - & & -0.01 & 1.1 & - & \\
\hline$\Delta_{8} \log$ housema 8 & - & & 0.10 & 2.4 & - & & 0.085 & 2.2 \\
\hline \multicolumn{9}{|c|}{ Diagnostics } \\
\hline s.e & \multicolumn{2}{|c|}{0.0110} & \multicolumn{2}{|c|}{0.0103} & \multicolumn{2}{|c|}{0.0102} & \multicolumn{2}{|c|}{0.0098} \\
\hline Adj. $R^{2}$ & \multicolumn{2}{|c|}{0.480} & \multicolumn{2}{|c|}{0.517} & \multicolumn{2}{|c|}{0.555} & \multicolumn{2}{|c|}{0.562} \\
\hline $\mathrm{DW}$ & \multicolumn{2}{|c|}{2.1} & \multicolumn{2}{|c|}{1.97} & \multicolumn{2}{|c|}{2.12} & \multicolumn{2}{|c|}{1.98} \\
\hline LM1 ( $p$ value) & \multicolumn{2}{|c|}{0.287} & \multicolumn{2}{|c|}{0.800} & \multicolumn{2}{|c|}{0.324} & \multicolumn{2}{|c|}{0.853} \\
\hline LM4 ( $p$ value) & \multicolumn{2}{|c|}{0.497} & \multicolumn{2}{|c|}{0.610} & \multicolumn{2}{|c|}{0.513} & \multicolumn{2}{|c|}{0.738} \\
\hline LMhet ( $p$ value) & \multicolumn{2}{|c|}{0.431} & \multicolumn{2}{|c|}{0.302} & \multicolumn{2}{|c|}{0.216} & \multicolumn{2}{|c|}{0.114} \\
\hline
\end{tabular}


Table 6: Estimates of the SA Consumption Function, 1971:1-2003:4

\begin{tabular}{|c|c|c|c|c|c|c|c|}
\hline \multirow{2}{*}{\multicolumn{2}{|c|}{$\begin{array}{r}\text { Dependent variable } \\
\Delta \log \mathrm{c}\end{array}$}} & \multicolumn{2}{|c|}{ No CCI terms } & \multicolumn{2}{|c|}{$\begin{array}{l}\text { CCI intercept effect; no } \\
\text { interaction effects }\end{array}$} & \multicolumn{2}{|c|}{$\begin{array}{l}\text { CCI intercept and } \\
\text { interaction effects } \\
\text { (parsimonious) }\end{array}$} \\
\hline & & coefficient & t- ratio & coefficient & t- ratio & coefficient & t- ratio \\
\hline $\begin{array}{l}\text { Speed of adjustment } \\
\text { (coeff. on } \log y-\log c_{-1} \text { ) }\end{array}$ & $\alpha$ & 0.21 & 5.9 & 0.42 & 8.0 & 0.45 & 10.5 \\
\hline Intercept & $\alpha_{0}$ & -0.27 & -2.4 & -0.12 & -3.0 & -0.10 & -2.9 \\
\hline $\mathrm{CCI}$ & 1 & - & & $\begin{array}{c}1 \\
\text { (normalization) } \\
\end{array}$ & & $\begin{array}{c}1 \\
\text { (normalization) } \\
\end{array}$ & \\
\hline Real rate ma4 & $\alpha_{1}$ & - & & -0.18 & -2.4 & -0.19 & -2.4 \\
\hline Real rate ma4 x CCI & $\alpha_{1 \mathrm{c}}$ & - & & - & & - & \\
\hline Uncertainty ( $\Delta_{2} \log$ cap util.) & $\alpha_{2}$ & - & & 0.12 & 0.9 & 0.66 & 3.7 \\
\hline $\begin{array}{l}\text { Uncertainty (Ex. Rate } \\
\text { volatility) }\end{array}$ & $\alpha_{2 \mathrm{a}}$ & & & -0.00 & 0.0 & -0.14 & -1.7 \\
\hline Uncertainty x CCI interaction & $\alpha_{2 \mathrm{c}}$ & - & & - & & $\begin{array}{c}-3.5 \\
\text { (fixed) }\end{array}$ & \\
\hline $\mathrm{E} \Delta \log$ yperm +12 & $\alpha_{3}$ & 0.23 & 1.2 & 0.32 & 3.3 & - & \\
\hline $\mathrm{E} \Delta \log$ yperm $+12 \quad$ x CCI & $\alpha_{3 c}$ & & & - & & 1.97 & 3.5 \\
\hline$\left(y^{\text {prop }} / y\right)$ & $\alpha_{4}$ & 0.42 & 5.4 & 0.14 & 3.2 & 0.10 & 2.8 \\
\hline Net liquid assets/income & $\gamma_{1}$ & 0.14 & 1.2 & 0.16 & 2.7 & 0.12 & 2.4 \\
\hline $\begin{array}{l}\text { Directly held illiquid financial } \\
\text { assets/income }\end{array}$ & $\gamma_{2}$ & 0.10 & 2.0 & 0.08 & 2.9 & 0.07 & 3.7 \\
\hline Pension assets/income & $\gamma_{2 \mathrm{a}}$ & 0.32 & 2.0 & 0.09 & 2.3 & 0.04 & 1.4 \\
\hline Housing wealth/income & $\gamma_{3}$ & 0.10 & 1.1 & 0.14 & 4.1 & 0.10 & 2.9 \\
\hline Housing wealth/income $\mathrm{x}$ CCI & $\gamma_{3 c}$ & - & & & & 0.22 & 0.9 \\
\hline$\Delta \log \mathrm{y}$ & $\beta_{1}$ & 0.14 & 3.1 & 0.04 & 0.9 & - & \\
\hline$\Delta \log \mathrm{y} \times \mathrm{CCI}$ & $\beta_{1 \mathrm{c}}$ & - & & & & - & \\
\hline $\begin{array}{l}\text { Debt/income weighted change } \\
\text { in log nominal interest rate }\end{array}$ & $\beta_{2}$ & -0.008 & -1.2 & -0.017 & -2.7 & -0.038 & -5.6 \\
\hline $\begin{array}{l}\text { Debt/income weighted change } \\
\text { in log nom. interest rate x CCI }\end{array}$ & $\beta_{2 c}$ & - & & & & - & \\
\hline \multicolumn{8}{|c|}{ Diagnostics } \\
\hline s.e & & & 0820 & & 0710 & \multicolumn{2}{|c|}{0.00668} \\
\hline $\mathrm{R}^{2}$ & & & 692 & & 769 & \multicolumn{2}{|c|}{0.796} \\
\hline DW & & & 25 & & 27 & \multicolumn{2}{|c|}{2.42} \\
\hline LM1 (p-value) & & & 137 & & 101 & \multicolumn{2}{|c|}{0.011} \\
\hline LM4 (p-value) & & & 502 & & 329 & \multicolumn{2}{|c|}{0.173} \\
\hline LMhet (p-value) & & & 593 & & 366 & & \\
\hline
\end{tabular}

Notes

a. Coefficients correspond to equation (5.5) which is based on the theory equation (3.11). b. All interaction terms are in the form of $(\mathrm{z}-$ mean $(\mathrm{z})) \times \mathrm{CCI}$, where the mean is computed over the 1981Q1 to 2003Q4 period in which CCI exceeds zero. 
Table 7: Estimates of the SA Debt Function, 1971:1-2003:4

\begin{tabular}{|c|c|c|c|c|c|c|c|}
\hline \multirow{2}{*}{\multicolumn{2}{|c|}{$\begin{array}{r}\text { Dependent variable } \\
\Delta \log \text { debt } \\
\text { Regressors }\end{array}$}} & \multicolumn{2}{|c|}{ No CCI terms } & \multicolumn{2}{|c|}{$\begin{array}{c}\text { CCI intercept } \\
\text { effect; no } \\
\text { interaction effects }\end{array}$} & \multicolumn{2}{|c|}{$\begin{array}{c}\text { CCI intercept and } \\
\text { interaction effects } \\
\text { (parsimonious) }\end{array}$} \\
\hline & & \multirow{2}{*}{$\begin{array}{c}\text { coefficient } \\
0.10\end{array}$} & \multirow{2}{*}{$\frac{t \text { - ratio }}{4.7}$} & \multirow{2}{*}{$\begin{array}{c}\text { coefficient } \\
0.17\end{array}$} & \multirow{2}{*}{$\frac{t \text { - ratio }}{3.7}$} & \multirow{2}{*}{$\frac{\text { coefficient }}{0.14}$} & \multirow{2}{*}{$\frac{t \text { - ratio }}{5.2}$} \\
\hline $\begin{array}{l}\text { Speed of adjustment } \\
\text { (coefficient. on } \\
\left.\log \mathrm{y}_{-1}-\log \text { debt }_{-1}\right)\end{array}$ & $\delta$ & & & & & & \\
\hline Intercept & $\delta_{0}$ & -17.4 & -3.7 & -14.4 & -3.9 & -15.6 & -4.6 \\
\hline $\mathrm{CCI}$ & & - & & 2.43 & 4.7 & 1.73 & 4.8 \\
\hline real rate ma $8_{-1}$ & $\delta_{1}$ & -1.29 & -2.1 & -0.71 & -1.9 & - & \\
\hline CCI $x$ real rate ma $8_{-1}$ & $\delta_{1 c}$ & - & & & - & -5.10 & -2.1 \\
\hline Uncertainty, $\theta$ & $\delta_{2}$ & - & & 1.66 & 0.9 & 0.62 & 3.2 \\
\hline $\mathrm{E} \Delta \log$ yperm $_{+12}$ & $\delta_{3}$ & - & & 0.08 & 1.3 & - & \\
\hline$\left(y^{\text {prop }} / y\right)$ & $\delta_{4}$ & 0.68 & 2.5 & 0.25 & 1.8 & 0.21 & 1.3 \\
\hline $\log y$ & $\delta_{5}$ & 1.81 & 3.6 & 1.47 & 4.6 & 1.61 & 4.4 \\
\hline Long run wealth elasticity ${ }^{\mathrm{a}}$ & $\phi_{1}$ & 1 & & 1 & & 1.10 & 4.6 \\
\hline $\log$ illiquid assets(-1)/y & $\phi_{2}$ & 0.17 & 2.1 & 0.18 & 3.4 & 0.26 & 3.9 \\
\hline $\log$ pension wealth(-1)/y & $\phi_{3}$ & 0.58 & 14.0 & 0.25 & 3.9 & 0.27 & 2.8 \\
\hline $\log$ housing wealth/y & $\phi_{4}$ & - & & 0.09 & 1.3 & - & \\
\hline $\begin{array}{c}\text { CCI x (log housing } \\
\text { wealth }(-1) / y-\log \text { liquid } \\
\text { assets }(-1) / y) \\
\end{array}$ & $\phi_{4 c}$ & - & & - & & 0.58 & 0.8 \\
\hline $\begin{array}{c}\Delta_{4} \log \text { nominal interest } \\
\text { rate }\end{array}$ & $\eta_{2}$ & -0.003 & -0.4 & -0.018 & -2.4 & -0.030 & -2.9 \\
\hline$\Delta_{8} \log$ population (ma4) & $\eta_{3}$ & 1.20 & 4.8 & 2.03 & 6.3 & 1.55 & 4.4 \\
\hline \multicolumn{8}{|c|}{ Diagnostics } \\
\hline \multicolumn{2}{|l|}{ s.e } & \multicolumn{2}{|c|}{0.0116} & \multicolumn{2}{|c|}{0.0101} & \multicolumn{2}{|c|}{0.0097} \\
\hline \multicolumn{2}{|l|}{$\mathrm{R}^{2}$} & \multicolumn{2}{|c|}{0.658} & \multicolumn{2}{|c|}{0.769} & \multicolumn{2}{|c|}{0.760} \\
\hline \multicolumn{2}{|l|}{ DW } & \multicolumn{2}{|c|}{1.47} & \multicolumn{2}{|c|}{1.74} & \multicolumn{2}{|c|}{1.93} \\
\hline \multicolumn{2}{|l|}{ LM1 ( $p$ value) } & \multicolumn{2}{|c|}{0.002} & \multicolumn{2}{|c|}{0.101} & \multicolumn{2}{|c|}{0.849} \\
\hline LM4 ( $p$ value) & & \multicolumn{2}{|c|}{0.008} & \multicolumn{2}{|c|}{0.329} & \multicolumn{2}{|c|}{0.426} \\
\hline \multicolumn{2}{|l|}{ LMhet } & \multicolumn{2}{|c|}{0.593} & \multicolumn{2}{|c|}{0.837} & 0.8 & \\
\hline
\end{tabular}

Note:

a. Long run wealth elasticity set to 1 for specifications 1 and 2 .

b. Coefficients correspond with equation (5.6).

c. All interaction terms are in the form of $(\mathrm{z}-$ mean $(\mathrm{z})) \mathrm{x}$ CCI, where the mean is computed over the 1980Q4 to 2001Q4 period in which CCI exceeds zero. 
Table 8: Estimates of the year dummies for CCI corresponding to Tables 6 and 7.

\begin{tabular}{|c|c|c|c|c|}
\hline $\begin{array}{c}\text { Dependent variable } \\
\Delta \log \text { debt }\end{array}$ & \multicolumn{2}{|c|}{$\begin{array}{c}\text { CCI intercept effect; } \text { no } \\
\text { interaction effects }\end{array}$} & \multicolumn{2}{c|}{$\begin{array}{c}\text { CCI intercept and } \\
\text { interaction } \text { effects } \\
\text { (parsimonious) }\end{array}$} \\
\hline Regressors & coefficient & t- ratio & coefficient & t-ratio \\
\hline D81 & 0.011 & 1.2 & 0.031 & 3.8 \\
\hline D83 & 0.043 & 3.6 & 0.023 & 2.2 \\
\hline D88 & 0.094 & 6.4 & 0.109 & 7.4 \\
\hline D89 & 0.024 & 1.7 & 0.034 & 2.7 \\
\hline D93 & 0.011 & 1.0 & 0.023 & 1.7 \\
\hline D95 & 0.052 & 4.5 & 0.067 & 6.0 \\
\hline
\end{tabular}


Figure 1: UK personal consumption and disaggregated assets relative to personal disposable non-property income

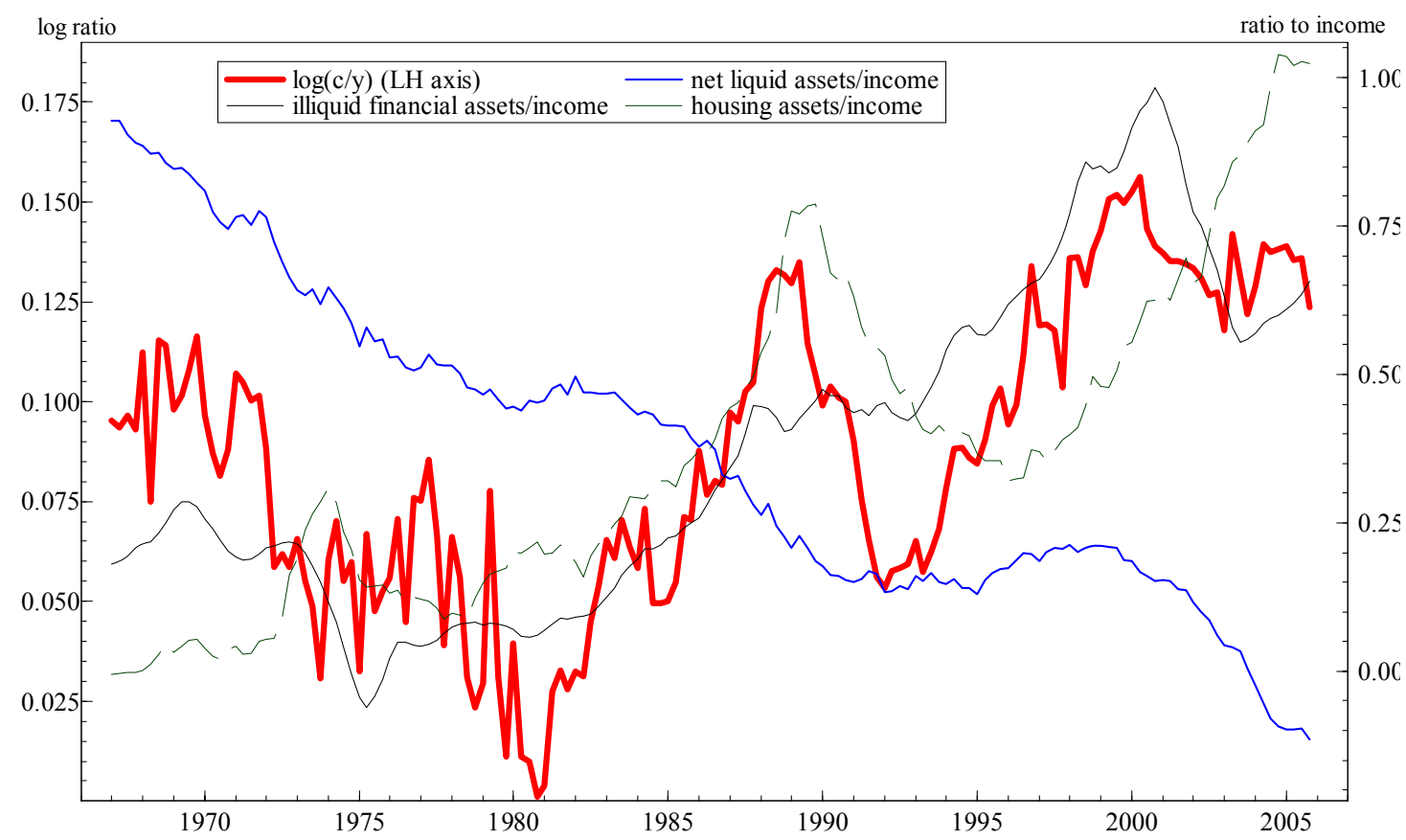

Note: Asset ratios have been range-adjusted on the RH axis.

Figure 2: Credit conditions index for the UK and the real interest rate

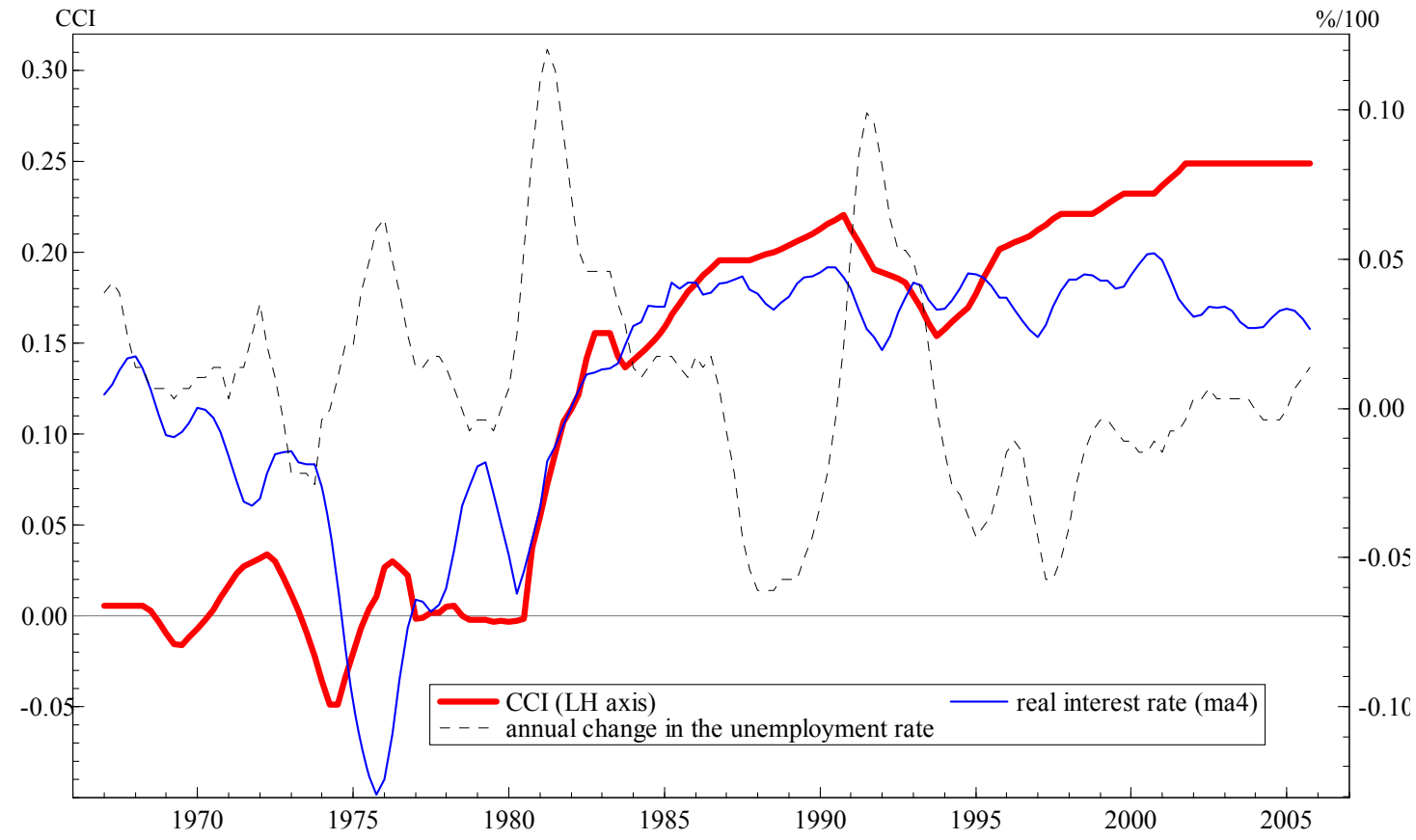


Figure 3: South African personal consumption and household debt relative to personal disposable non-property income

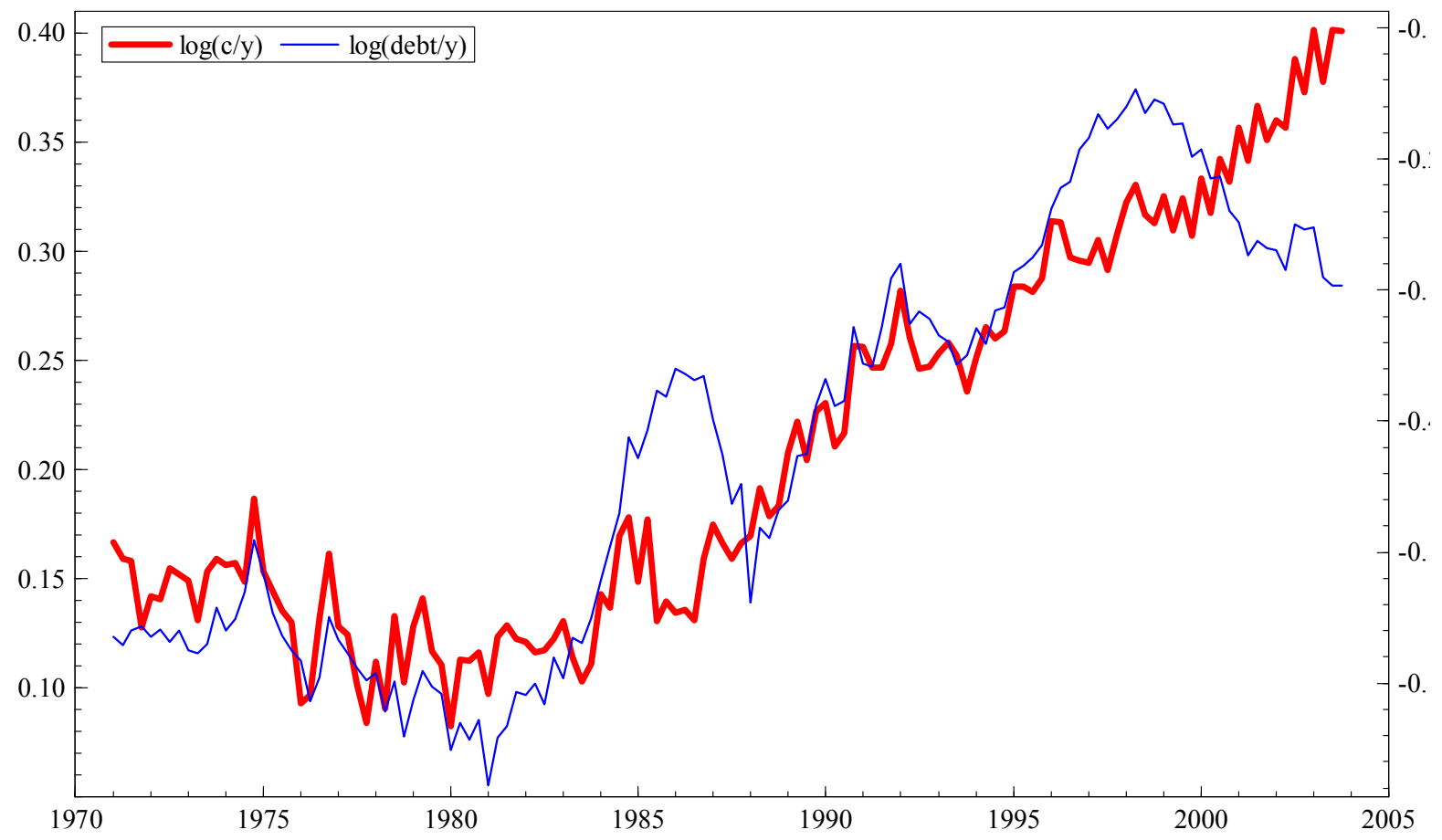

Figure 4: South African debt, liquid and illiquid assets relative to personal disposable non-property income

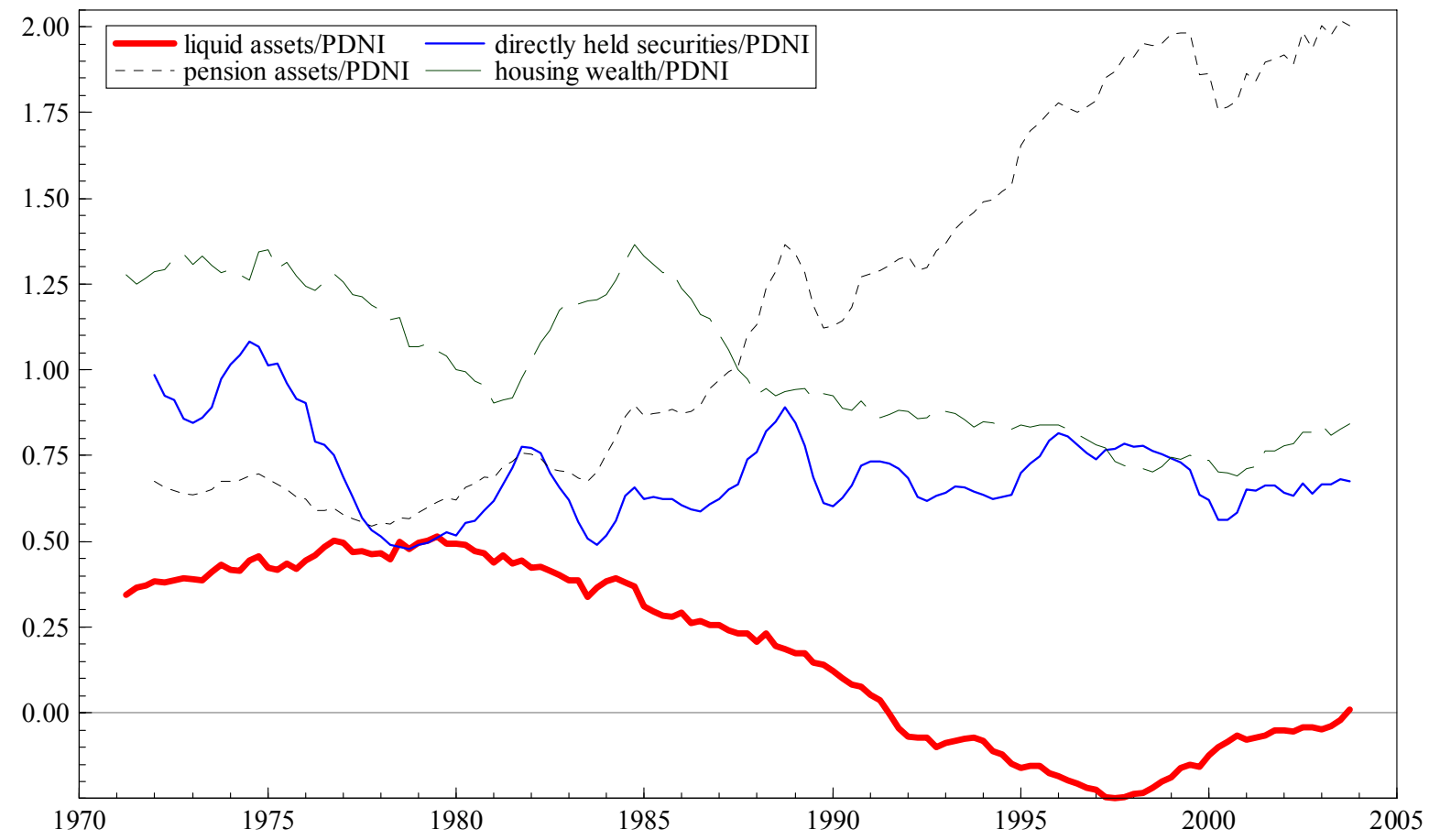


Figure 5: Credit conditions index for South Africa and the real interest rate

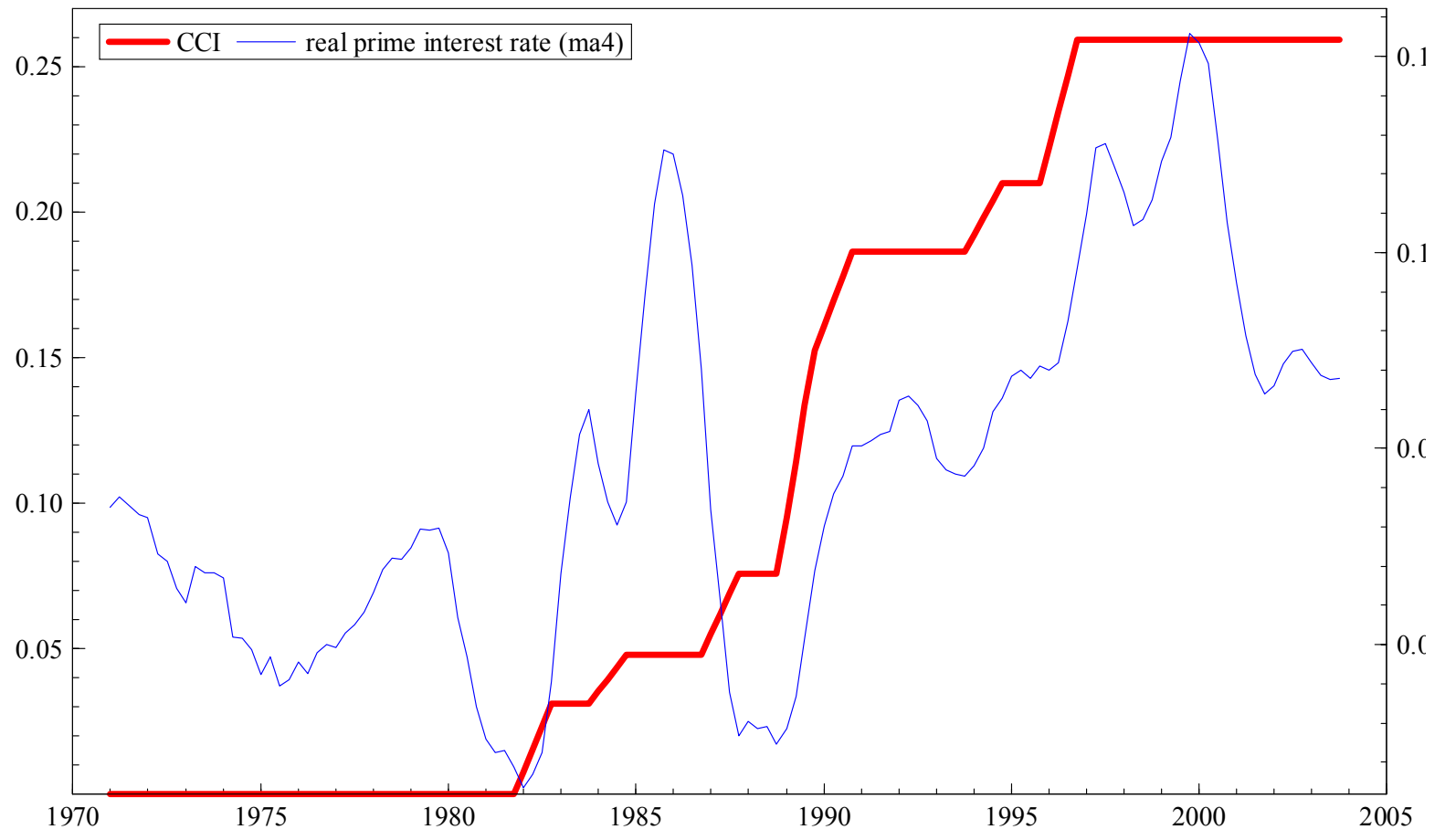




\section{Appendix}

\section{Derivation of equation (3.11)}

One expects $\phi_{1 \mathrm{t}}>0$ and $\phi_{2 \mathrm{t}}<0$, since credit-constrained households, on average, are likely to have lower incomes. We now make the simplifying assumption that $\phi_{1 \mathrm{t}}$ and $\phi_{2 \mathrm{t}}$ evolve slowly, so that $\Delta \log y_{t}^{c} \approx \Delta \log y_{t}$.

By definition, if $\pi_{t}^{y}$ is the income share of credit-constrained households,

$$
\left(1-\pi_{t}^{y}\right) \phi_{1 t}+\pi_{t}^{y} \phi_{2 t} \approx 0
$$

since $\log y_{t} \approx\left(1-\pi_{t}^{y}\right) \log y_{t}^{u}+\pi_{t}^{y} \log y_{t}^{c}$.

It follows that

$$
\phi_{1 t} / \phi_{2 t}=-\pi_{t}^{y} /\left(1-\pi_{t}^{y}\right)
$$

This expression implies that $\phi_{1 t}$ and $\phi_{2 t}$ are, respectively, proportional to $\pi_{t}^{y}$ and $-\left(1-\pi_{t}^{y}\right)$, with the factor of proportionality depending, among other things, on $\pi_{t}^{y}$ and the shape of the income distribution. Note that the consumption share, $\pi_{\mathrm{t}}$, and the income share, $\pi_{t}^{u}$, of creditconstrained households do not coincide, though they should be highly correlated over time.

To obtain the average consumption function, note that

$$
\Delta \log c_{t}=\left(1-\pi_{t}\right) \Delta \log c_{t}^{u}+\pi_{t} \Delta \log c_{t}^{c}
$$

Consumption growth for those unconstrained by credit, $\Delta \log c_{t}^{u}$, can be expressed by rewriting equation (3.6) as

$$
\Delta \log c_{t}^{u}=\beta\left[f\left(x_{t}\right)+\log y_{t}^{u}+\gamma A_{t-1}^{u} / y_{t}^{u}-\log c_{t-1}^{u}\right]+\varepsilon_{t}
$$

For the credit-constrained, the consumption growth, $\Delta \log c_{t}^{u}$, is 


$$
\Delta \log c_{t}^{c} \approx \Delta \log y_{t}
$$

Now substitute (A.4) and (A.5) into (A.3) to obtain an expression for $\Delta \log \mathrm{c}_{\mathrm{t}}$. From equation (3.7), the expression $\log c_{t-1}^{u} \cong\left[\log c_{t-1}-\pi_{t-1}\left(\phi_{2 t-1}+\log y_{t-1}\right)\right] /\left(1-\pi_{t-1}\right)$ can be substituted into the resulting equation for $\Delta \log c_{t}$. The result further simplifies by using the assumption that $\pi_{t}$ as well as $\phi_{1 \mathrm{t}}$ and $\phi_{2 \mathrm{t}}$ evolve only slowly, so that $\pi_{t-1} \approx \pi_{t}$ and $\phi_{2 t-1} \approx \phi_{2 t}$. Note that the asset holdings of unconstrained households will equal the average per capita asset level, if creditconstrained households hold no assets i.e. $\left(1-\pi_{t}\right) A_{t-1}^{u}=A_{t-1}$. Then, substituting into equation (A.4) gives equation (3.11). 